\title{
Characterization of aerosol chemical composition with aerosol mass spectrometry in Central Europe: an overview
}

\author{
V. A. Lanz ${ }^{1}$, A. S. H. Prévôt ${ }^{1}$, M. R. Alfarra ${ }^{1,2}$, S. Weimer ${ }^{1,3}$, C. Mohr ${ }^{1}$, P. F. DeCarlo ${ }^{1}$, M. F. D. Gianini ${ }^{4}$, C. Hueglin ${ }^{4}$, \\ J. Schneider ${ }^{5}$, O. Favez ${ }^{6,7}$, B. D'Anna ${ }^{6,7}$, C. George ${ }^{6,7}$, and U. Baltensperger ${ }^{1}$ \\ ${ }^{1}$ Paul Scherrer Institut, Laboratory of Atmospheric Chemistry, 5232 Villigen PSI, Switzerland \\ ${ }^{2}$ Centre for Atmospheric Sciences, School of Earth, Atmospheric and Environmental Sciences, University of Manchester, \\ Manchester, M60 1QD, UK \\ ${ }^{3}$ Empa, Swiss Federal Laboratories for Materials Testing and Research, Laboratory for Internal Combustion Engines, 8600 \\ Duebendorf, Switzerland \\ ${ }^{4}$ Empa, Swiss Federal Laboratories for Materials Testing and Research, Laboratory for Air Pollution and Environmental \\ Technology, 8600 Duebendorf, Switzerland \\ ${ }^{5}$ Particle Chemistry Dept., Max Planck Institute for Chemistry, Mainz, Germany \\ ${ }^{6}$ Université Lyon 1, Lyon, 69626, France \\ ${ }^{7}$ Institut de recherches sur la catalyse et l'environnement de Lyon, CNRS, UMR5256, IRCELYON, Villeurbanne, \\ 69626, France
}

Received: 8 October 2009 - Published in Atmos. Chem. Phys. Discuss.: 24 November 2009

Revised: 27 August 2010 - Accepted: 4 November 2010 - Published: 8 November 2010

\begin{abstract}
Real-time measurements of non-refractory submicron aerosols $\left(\mathrm{NR}-\mathrm{PM}_{1}\right)$ were conducted within the greater Alpine region (Switzerland, Germany, Austria, France and Liechtenstein) during several week-long field campaigns in 2002-2009. This region represents one of the most important economic and recreational spaces in Europe. A large variety of sites was covered including urban backgrounds, motorways, rural, remote, and high-alpine stations, and also mobile on-road measurements were performed. Inorganic and organic aerosol (OA) fractions were determined by means of aerosol mass spectrometry (AMS). The data originating from 13 different field campaigns and the combined data have been utilized for providing an improved temporal and spatial data coverage.

The average mass concentration of NR-PM $\mathrm{P}_{1}$ for the different campaigns typically ranged between 10 and $30 \mu \mathrm{g} \mathrm{m}^{-3}$. Overall, the organic portion was most abundant, ranging from $36 \%$ to $81 \%$ of $\mathrm{NR}-\mathrm{PM}_{1}$. Other main constituents comprised ammonium (5-15\%), nitrate (8-36\%), sulfate (3$26 \%$ ), and chloride $(0-5 \%)$. These latter anions were, on average, fully neutralized by ammonium. As a major result, time of the year (winter vs. summer) and location of
\end{abstract}

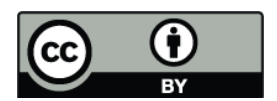

Correspondence to: A. S. H. Prévôt (andre.prévôt@psi.ch) the site (Alpine valleys vs. Plateau) could largely explain the variability in aerosol chemical composition for the different campaigns and were found to be better descriptors for aerosol composition than the type of site (urban, rural etc.). Thus, a reassessment of classifications of measurements sites might be considered in the future, possibly also for other regions of the world.

The OA data was further analyzed using positive matrix factorization (PMF) and the multi-linear engine ME (factor analysis) separating the total OA into its underlying components, such as oxygenated (mostly secondary) organic aerosol (OOA), hydrocarbon-like and freshly emitted organic aerosol (HOA), as well as OA from biomass burning (BBOA). OOA was ubiquitous, ranged between $36 \%$ and $94 \%$ of OA, and could be separated into a low-volatility and a semi-volatile fraction (LV-OOA and SV-OOA) for all summer campaigns at low altitude sites. Wood combustion (BBOA) accounted for a considerable fraction during wintertime (17-49\% OA), particularly in narrow Alpine valleys BBOA was often the most abundant OA component. HOA/OA ratios were comparatively low for all campaigns (6-16\%) with the exception of on-road, mobile measurements $(23 \%)$ in the Rhine Valley. The abundance of the aerosol components and the retrievability of SV-OOA and LV-OOA are discussed in the light of atmospheric chemistry and physics.

Published by Copernicus Publications on behalf of the European Geosciences Union. 


\section{Introduction}

Atmospheric aerosols are currently a subject of high scientific and political interest due to their important effects on climate (Forster et al., 2007), human health (Peng et al., 2005), ecosystems and agricultural yields (acidification and eutrophication; Matson et al., 2002), as well as visibility (Watson, 2002). Particulate matter (PM) in the air represents a complex mixture of organic matter, inorganic salts, trace elements, mineral dust, elemental carbon and water suspended in the air. Detailed analyses of physicochemical properties and spatiotemporal variability are crucial to understand the mechanisms of aerosol toxicity (Peng et al., 2005) and their role in climate change (IPCC, 2007). The identification and quantification of processes and sources that govern global and regional aerosol abundances are the indispensable basis for efficient abatement strategies.

During the last decades, a growing number of scientific studies have been investigating the chemical composition of $\mathrm{PM}_{10}$ and $\mathrm{PM}_{2.5}$ (particulate matter with an aerodynamic diameter of 10 and $2.5 \mu \mathrm{m}$ or less, respectively) using offline filter analyses, see e.g. Putaud et al. (2004) and Hueglin et al. (2005) for Europe and for the years 1991-2001. The recent development of online aerosol mass spectrometers (AMS) allows scrutinizing non-refractory material at high time-resolution and examining the sources of the organic aerosol fraction (e.g., Canagaratna et al., 2007). This technology has been dedicated to the investigation of submicron particles $\left(\mathrm{PM}_{1}\right)$, which could be more detrimental to human health than larger ones (e.g., with respect to respiratory diseases; Ramgolam et al., 2009).

This paper represents an overview of AMS studies on the aerosol chemical composition in the greater Alpine area during 2002-2009. The chemical composition of non-refractory $\mathrm{PM}_{1}$ (and black carbon, $\mathrm{BC}$ ) is investigated here for various sites in five different countries (Switzerland, Germany, Austria, France and Liechtenstein), representing one of the most important economic and leisure areas in Europe. This metaanalysis extensively investigates the organic material (OM), its underlying components as well as the inorganic aerosol fractions (ammonium, nitrate, sulfate, and chloride) and their ion balance for all the 13 campaigns at the 10 measuring sites. The results obtained in this study are furthermore compared to previous similar studies.

Zhang et al. (2007a) recently provided an overview on AMS data $\left(\mathrm{NR}-\mathrm{PM}_{1}\right)$ for the Northern Hemisphere with a main focus on summer campaigns and the dichotomy of oxygenated and hydrocarbon-like OA (OOA vs. HOA). The pre-alpine (i.e., at the foothills of the Alps) site Hohenpeissenberg and the high-alpine site Jungfraujoch (but represented by different campaigns) are part of Zhang et al. (2007a) and this study. However, as shown here, these remote background locations are not representative of other regions of the greater Alpine area/Central Europe: more different types of measuring sites need to be consid- ered. In this study, additionally analyzed datasets comprise aerosol mass spectrometric measurements from an alpine village (Roveredo), a rural-agricultural (Payerne) and a ruralindustrial (Massongex) site, two stations each at urban backgrounds (Zürich, Grenoble) and rural-kerbsides (Reiden, Härkingen) as well as on-road mobile measurements in the Alpine Rhine Valley (Table 1). Alfarra et al. (2007), Lanz et al. (2007, 2008), and Favez et al. (2010) have already described the OA composition and origin for three sampling locations (Roveredo, Zürich, and Grenoble, respectively). The presentation of results of in-depth OA analyses for the other sites is in preparation, e.g. by Mohr et al. (2010) for the Rhine Valley and by Perron et al. (2010) for Massongex. The AMS campaign at Hohenpeissenberg (Germany) was detailed by Hock et al. (2008). In this work, we further discuss both the organic as well as the inorganic fraction in detail. We applied factor analytical approaches to organic aerosol mass spectra (FA-AMS) that allowed identification and quantification of the main organic subfractions, such as OOA (oxygenated organic aerosol), HOA (hydrocarbon-like organic aerosol), but also other distinct OA components, such as BBOA (biomass burning organic aerosol). The used methods are based on positive matrix factorization (PMF, Paatero and Tapper, 1993, 1994) and the multilinear engine (ME; Paatero, 1999); their application to AMS organic data was described in detail earlier (Lanz et al., 2007, 2008; Ulbrich et al., 2009). Most importantly, we show that wood burning OA, BBOA, makes up for a substantial fraction of OA and must no longer be ignored, at least in Central Europe. This manuscript gives insights into the seasonal and spatial variability (including vertical difference) in the OA and total AMS-aerosol for Central Europe. In this respect, we go beyond the temporal and spatial resolution of the overviews on the Northern Hemisphere by Zhang et al. (2007) and Jimenez et al. (2009), which do not cover the spatial gradients of the OA composition in such detail.

\section{Methods}

\subsection{Measurement sites and campaigns}

Aerodyne aerosol mass spectrometers (quadrupole based QAMS, standard time-of-flight ToF-AMS, and high-resolution time-of-flight HR-ToF-AMS) were deployed at various sites in Central Europe (Fig. 1). Usually, an AMS was deployed during 2- to 3-week campaigns in the years 2002 and 20052009 (for details see Table 1). Six sampling sites were located in the Alps or Pre-Alps (Massongex, Jungfraujoch, Roveredo, Rhine Valley, Grenoble and Hohenpeissenberg) and four sampling sites in the Swiss Plateau (Payerne, Härkingen, Reiden and Zürich). The Alpine measurement locations can be separated into low altitude and elevated sites. Low altitude sites (between 200 and $500 \mathrm{~m}$ a.s.1.) comprise Massongex, Roveredo, the Rhine Valley and Grenoble, 
Table 1. Sampling sites, altitude (meters above sea level, $\mathrm{m}$ a.s.1.), type and position of the site (A=Alpine region, SP=Swiss Plateau), duration of the AMS field campaigns, abbreviation, and ambient temperature (in ${ }^{\circ} \mathrm{C}$ ), as well as related publications. Quadrupole aerosol mass spectrometers (Q-AMS) were deployed in all campaigns with the exceptions of Jungfraujoch and Grenoble, where time-of-flight mass spectrometers (ToF-AMS) were used. (Country codes: $\mathrm{CH}=$ Switzerland, AT=Austria, LI=Liechtenstein, $\mathrm{DE}=\mathrm{Germany}, \mathrm{FR}=\mathrm{France}$ ).

\begin{tabular}{|c|c|c|c|c|c|c|}
\hline $\begin{array}{l}\text { measuring site } \\
\text { (country, altitude) }\end{array}$ & type & position & date & abbreviation & $T_{\text {avg }}\left(T_{\min }, T_{\max }\right)$ & publication \\
\hline $\begin{array}{l}\text { Rhine Valley } \\
\text { (CH/AT/LI, } 400 \mathrm{~m} \text { a.s.l.) }\end{array}$ & $\begin{array}{l}\text { mobile/ } \\
\text { on-road }\end{array}$ & A & $\begin{array}{l}\text { 16-22 Feb 2007/ } \\
8-13 \mathrm{Feb} 2008\end{array}$ & RHI FEB_2007 & $+04(-03,+14)$ & Weimer et al., 2009 \\
\hline $\begin{array}{l}\text { Zürich } \\
\text { (CH, } 410 \text { m a.s.l.) }\end{array}$ & $\begin{array}{l}\text { urban/ } \\
\text { background }\end{array}$ & SP & $\begin{array}{l}\text { 14 Jul-4 Aug } 2005 \\
6-25 \text { Jan } 2006\end{array}$ & $\begin{array}{l}\text { ZUE JUL_2005 } \\
\text { ZUE JAN_2006 }\end{array}$ & $\begin{array}{l}+23(+15,+35) \\
+00(-07,+07)\end{array}$ & $\begin{array}{l}\text { Lanz et al., } 2007 \\
\text { Lanz et al., } 2008\end{array}$ \\
\hline $\begin{array}{l}\text { Grenoble } \\
\text { (FR, } 220 \text { m a.s.1.) }\end{array}$ & $\begin{array}{l}\text { urban/ } \\
\text { background }\end{array}$ & $\mathrm{A}$ & 14-30 Jan 2009 & GRE JAN_2009 & $+04(-07,+14)$ & Favez et al., 2010 \\
\hline $\begin{array}{l}\text { Massongex } \\
\text { (CH, } 310 \mathrm{~m} \text { a.s.l.) }\end{array}$ & $\begin{array}{l}\text { rural/ } \\
\text { industrial }\end{array}$ & A & 23 Nov-17 Dec 2006 & MAS DEC_2006 & $+08(-02,+22)$ & Perron et al., 2010 \\
\hline $\begin{array}{l}\text { Härkingen } \\
(\mathrm{CH}, 430 \mathrm{~m} \text { a.s.l. })\end{array}$ & $\begin{array}{l}\text { rural/ } \\
\text { motorway }\end{array}$ & SP & 12-30 May 2005 & HAE MAY_2005 & $+14(+04,+32)$ & \\
\hline $\begin{array}{l}\text { Reiden } \\
\text { (CH, } 460 \text { m a.s.l.) }\end{array}$ & $\begin{array}{l}\text { rural/ } \\
\text { motorway }\end{array}$ & SP & 27 Jan-13 Feb 2006 & REI FEB_2006 & $+00(-08,+09)$ & \\
\hline $\begin{array}{l}\text { Roveredo } \\
(\mathrm{CH}, 300 \mathrm{~m} \text { a.s.1. })\end{array}$ & $\begin{array}{l}\text { residential/ } \\
\text { motorway }\end{array}$ & A & $\begin{array}{l}1-15 \text { Mar } 2005 \\
25 \text { Nov-15 Dec } 2005\end{array}$ & $\begin{array}{l}\text { ROV MAR_2005 } \\
\text { ROV DEC_2005 }\end{array}$ & $\begin{array}{l}+03(-07,+15) \\
-01(-06,+04)\end{array}$ & $\begin{array}{l}\text { Alfarra et al., } 2007 \\
\text { Alfarra et al., } 2007\end{array}$ \\
\hline $\begin{array}{l}\text { Payerne } \\
\text { (CH, } 490 \text { m a.s.l.) }\end{array}$ & $\begin{array}{l}\text { rural/ } \\
\text { agricultural }\end{array}$ & SP & $\begin{array}{l}31 \text { May-3 Jul } 2006 \\
\text { 12 Jan-17 Feb } 2007\end{array}$ & $\begin{array}{l}\text { PAY JUN_2006 } \\
\text { PAY JAN_2007 }\end{array}$ & $\begin{array}{l}+18(+03,+31) \\
+03(-11,+14)\end{array}$ & \\
\hline $\begin{array}{l}\text { Hohenpeissenberg } \\
\text { (DE, } 985 \text { m a.s.l.) }\end{array}$ & remote & A & 19-31 Мay 2002 & MOHp MAY_2002 & $+13(+04,+32)$ & Hock et al., 2008 \\
\hline $\begin{array}{l}\text { Jungfraujoch } \\
(\mathrm{CH}, 3580 \mathrm{~m} \text { a.s.1.) }\end{array}$ & remote & A & 30 Apr-29 May 2008 & JFJ MAY_2008 & $-04(-09,+02)$ & \\
\hline
\end{tabular}

which are - in contrast to the elevated sites Jungfraujoch (3580 $\mathrm{m}$ a.s.1.) and Hohenpeissenberg (985 $\mathrm{m}$ a.s.1.) - all situated in relatively narrow valleys. The Swiss Plateau (see Fig. 1) is a hilly basin (300-700 m a.s.1.) confined by the Jura mountains in the Northwest, by the Alps in the Southeast and by Lakes Geneva and Constance (Rhine river). The Swiss Plateau climate is in between humid oceanic (the predominant wind comes from the West/Atlantic ocean) and continental temperate. The individual sites are characterized in Table 1 and references therein. Jungfraujoch, Härkingen, Zürich and Payerne are part of NABEL, the Swiss National Air Pollution Monitoring Network (www.empa.ch/nabel).

\subsection{Aerosol mass spectrometry}

Aerosol mass spectra were obtained using three types of aerosol mass spectrometers (AMS, Aerodyne Research Inc.) at $2-15 \mathrm{~min}$ resolution for the fixed measurement locations and $1 \mathrm{~min}$ averages for the mobile campaigns in the Rhine Valley. A detailed description of the AMS instruments can be found in Canagaratna et al. (2007), and references therein. In principle, aerosols are introduced through a critical orifice, separated from gaseous species by a series of aerodynamic lenses, focused into a particle beam and directed onto a vaporizer. After vaporization (at about $600^{\circ} \mathrm{C}$ ) and electron ionization at $70 \mathrm{eV}$, the chemical composition is determined by the analysis of the resulting mass spectrum measured by a quadrupole (Q-AMS) or a Time-of-Flight mass spectrometer (ToF-AMS). The AMS measures the non-refractory fraction of submicron aerosol particles, which include components that evaporate at the standard vaporizer temperature of approximately $600^{\circ} \mathrm{C}$ and excludes elemental carbon, sea-salt, metals, and crustal material. Several trace elements such as potassium $(\mathrm{K})$ or sodium $(\mathrm{Na})$ can not be determined quantitatively by the AMS, as only the non-refractory (NR) portion of the aerosol is measured by this type of instrument. In addition, the quantification of water is challenging due to interferences with background air and other aerosol ions. Water was estimated to be a main constituent of airborne PM (Hueglin et al., 2005).

The use of the HR-ToF-AMS (DeCarlo et al., 2006) allows for the unit mass peaks to be separated into their contributing ion fragments and for the determination of their elemental composition (e.g., the separation of $\mathrm{C}_{4} \mathrm{H}_{9}^{+}$and $\mathrm{C}_{3} \mathrm{H}_{5} \mathrm{O}^{+}$at $m / z$ 57). The HR-ToF-AMS instrument was deployed in only one (Jungfraujoch) out of 13 campaigns and 


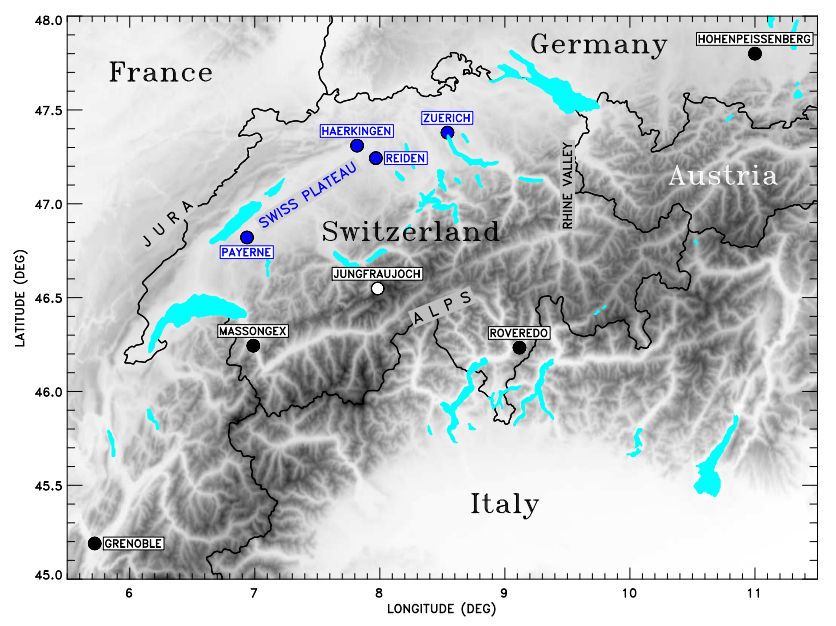

Fig. 1. AMS-campaigns in Central Europe conducted in the years 2002 and 2005-2009. Four sampling sites (Payerne, Härkingen, Reiden, and Zürich) are located in the Swiss Plateau (between Alps and Jura) and represented in blue, the others in the greater Alpine region (Grenoble, Massongex, Jungfraujoch, Roveredo, Rhine Valley, and Hohenpeissenberg). Ten campaigns took place in Switzerland (country borders indicated by black solid lines) (Härkingen, Payerne $2 \times$, Reiden, Zürich $2 \times$, Massongex, Jungfraujoch, Roveredo $2 \times$ ), and one in Germany (Hohenpeissenberg) and France (Grenoble) each. The mobile measurements in the (Alpine) Rhine Valley covered Switzerland, Austria, and Liechtenstein (not labelled).

the corresponding data were analyzed at unit mass resolution (UMR, as for the Q-AMS). A standard ToF-AMS as characterized in Drewnick et al. (2005) was used in Grenoble. The measured particles approximately cover the size range of $\mathrm{PM}_{1.0}$ for all AMS instruments. A vacuum aerodynamic diameter can be calculated from particle time-of-flight (PTOF) measurements (DeCarlo et al., 2004). However, this study focuses solely on the chemical composition data obtained from the entire particle population sampled by the AMS.

The UMR Q-AMS data were analyzed using the Igorbased software package described by Allan et al. (2003, 2004): in summary, the measured ion current is converted into the mass concentration using the measured ionization efficiency (IE) of nitrate, with which the instrument was calibrated (using pure ammonium nitrate particles; Jayne et al., 2000). For the other species, an IE relative to nitrate (RIE) is used (calibrated in laboratory studies; Jimenez et al., 2003; Allan et al., 2004; Alfarra, 2004). Organics were defined as the difference between signals from the total and inorganic aerosol (ammonium, sulfate, nitrate and chloride) for peaks with known organic contributions; organics determined by this method include the elements carbon (C), oxygen $(\mathrm{O})$, hydrogen $(\mathrm{H})$, and nitrogen $(\mathrm{N})$ (i.e., they represent organic matter, OM). The principles of PAH quantification using the Q-AMS were provided by Dzepina et al. (2007). ToF-AMS data was analyzed with the ToF-AMS toolkit available from http://cires.colorado.edu/jimenez-group/ ToFAMSResources/ToFSoftware/index.html.

\subsection{Ancillary measurements and AMS collection efficiency}

\subsubsection{Determination of AMS collection efficiency}

A collection efficiency (CE) of the AMS instrument is needed in order to estimate absolute mass concentrations of the aerosols (Alfarra et al., 2004). The CE is closely related to particle characteristics and aerosol phase, shape, chemical composition, size etc. were found to prominently affect the CE in laboratory studies (Matthew et al., 2008): high CEs may be due to liquid(-coated), spherical particles as a result of high relative humidity (in the sampling line as well as in ambient air), high nitrate/water content of the aerosol, aerosol size mass distribution showing a minor fraction of super-micron mass, etc. For further reading we refer to Canagaratna et al. (2007).

Offline filter analyses $\left(\mathrm{PM}_{1}\right.$ inlet in Zurich and Roveredo, $\mathrm{PM}_{2.5}$ in Grenoble, and $\mathrm{PM}_{10}$ in Reiden) were performed to compare ambient sulfate concentrations measured by the AMS and ion chromatography, and where available derive an AMS collection efficiency (assuming that CEs were approximately constant within one campaign). Ambient sulfate concentrations from offline filter measurements were compared to online AMS-sulfate and campaign-specific CEs were derived, assuming for example that refractory sulfates such as $\mathrm{K}_{2} \mathrm{SO}_{4}$ only negligibly contributed. Comparisons with other ancillary data were considered less robust (e.g., gravimetric reference methods may not represent the true total $\mathrm{PM}_{1}$ due to losses of volatile aerosol components such as $\mathrm{NH}_{4} \mathrm{NO}_{3}$ and semi-volatile $\mathrm{OM}$ ) and were not used in this context. A CE of unity for Jungfraujoch and CE $=0.5$ for Hohenpeissenberg (see Hock et al., 2008) was validated by SMPS and nephelometer/OPC (optical particle counter) data. In Table 2, mass concentration ranges for $\mathrm{CE}=0.5 \ldots 1.0$ are reported for the other cases. $\mathrm{CE}=0.5$ represents the default value (Canagaratna et al., 2007, and references therein) which is in agreement with the parameterized treatments of Crosier et al. (2007) and Matthew et al. (2008). However, CEs up to 1.0 have been reported in the literature for ambient particles (Kleinman et al., 2007, Takegawa et al., 2009; Sun et al., 2010) and there are indications that CE was at unity for some of the campaigns listed here as well. Thus, the average aerosol concentrations for certain campaigns included in Table 2 may be smaller by a factor of 0.5 compared to the mass concentration at default CE. Due to incomplete or inappropriate ancillary data we are not in the position to give unambiguous proof of such high CEs in those cases and thus the concentration at $\mathrm{CE}=1$ given in Table 2 represents a lowest estimate. However, we for the most part discuss the relative values hereafter (e.g., sulfate vs. total AMS-aerosol in Sect. 3.1), which are independent of CEs under the assumption of internally mixed aerosols. 
Table 2. Average ambient concentrations (arithmetic mean, $\mu$, and geometric mean, $\mu_{\text {geom }}$, in $\left[\mu \mathrm{g} \mathrm{m}^{-3}\right]$ ) for the non-refractory aerosol as measured by the AMS instruments $\left(\mathrm{NR}-\mathrm{PM}_{1}\right)$ for all campaigns (abbreviations see Table 1). The geometric mean was calculated by omitting non-positive values and the standard deviation of this mean was typically about $1 \mu \mathrm{g} \mathrm{m}{ }^{-3}$. The standard deviation of the arithmetic mean is $0.5 \%-2 \%$ of the total concentrations given by $\mu\left(\mathrm{NR}-\mathrm{PM}_{1}\right)$. Larger uncertainties are associated with the choice of the collection efficiency (CE) of the AMS instrument. It is indicated below how the CE was determined: type of ancillary measurements involved or typical range derived from the literature (see Sect. 2.3.1). Conversion factors to STP, $f_{\mathrm{STP}}$, were calculated as the ratio $f_{\mathrm{STP}}=\left(p^{\circ} T\right) /\left(p T^{\circ}\right)$, where standard temperature, $T^{\circ}=273.15 \mathrm{~K}$, and pressure, $p^{\circ}=101325 \mathrm{~Pa}$. Averages for black carbon, BC (or elemental carbon, EC), are given in $\left[\mu \mathrm{g} \mathrm{m}^{-3}\right]$ and their relative fractions in $[\%]$ of $\mathrm{NR}-\mathrm{PM}_{1}+\mathrm{BC}$ were calculated as $\mathrm{BC} /\left(\mathrm{NR}-\mathrm{PM} \mathrm{M}_{1}+\mathrm{BC}\right)$. $(*=\mathrm{CE}$ determined from sulfate filter measurements: these comparisons, AMS-sulfate vs. IC-sulfate, are based on typically $n=4$ samples and CE associated uncertainties up to $3 \cdot \operatorname{std}=0.18$ were calculated in orthogonal distance regressions through the origin.)

\begin{tabular}{|c|c|c|c|c|c|c|c|}
\hline campaign (abbrev.) & $\mu\left(\mathrm{NR}-\mathrm{PM}_{1}\right)$ & rel. std. dev. & $\mu_{\text {geom }}\left(\mathrm{NR}-\mathrm{PM}_{1}\right)$ & $\mathrm{CE}$ & CE det. & $f_{\mathrm{STP}}$ & $\mathrm{BC}\left[\% \mathrm{NR}-\mathrm{PM}_{1}+\mathrm{BC}\right.$ \\
\hline ZUE JUL_2005 & $9.6 \ldots 19.2$ & $0.52 \%$ & $8.1 \ldots 16.3$ & $1.0 \ldots 0.5$ & literature & 1.13 & $1.5[7 \ldots 14 \%]$ \\
\hline GRE JAN_2009 & 14.8 & $0.74 \%$ & 10.2 & $0.5^{*}$ & $\mathrm{PM}_{2.5}-\mathrm{SO}_{4}^{2-}$ & 1.10 & $2.2[13 \%]$ \\
\hline MAS DEC_2006 & $4.0 \ldots 7.9$ & $1.53 \%$ & $2.6 \ldots 5.1$ & $1.0 \ldots 0.5$ & literature & 1.13 & $1.7[18 \ldots 30 \%]$ \\
\hline HAE MAY_2005 & $12.5 \ldots 25.0$ & $0.48 \%$ & $10.8 \ldots 21.6$ & $1.0 \ldots 0.5$ & literature & 1.13 & BC not measured \\
\hline ROV DEC_2005 & 28.6 & $1.00 \%$ & 21.1 & $0.67 *$ & $\mathrm{PM}_{1}-\mathrm{SO}_{4}^{2-}-$ & 1.12 & $2.9[9 \%]$ \\
\hline PAY JUN_2006 & $9.7 \ldots 19.4$ & $0.72 \%$ & $8.7 \ldots 17.4$ & $1.0 \ldots 0.5$ & literature & 1.14 & BC not measured \\
\hline PAY JAN_2007 & $16.2 \ldots 32.3$ & $1.05 \%$ & $11.7 \ldots 23.4$ & $1.0 \ldots 0.5$ & lliterature & 1.14 & $1.1[3 \ldots 6 \%]$ \\
\hline MOHp MAY_2002 & 6.7 & $1.65 \%$ & 4.6 & 0.5 & SMPS/OPC & 1.22 & $0.3[4 \%]$ \\
\hline JFJ MAY_2008 & 1.6 & $1.89 \%$ & 0.8 & 1.0 & SMPS/neph. & 1.67 & $0.1[7 \%]$ \\
\hline
\end{tabular}

While the NR-PM 1 as well as the OA composition in Zürich, January 2006, and Reiden, February 2006, was very similar (Figs. 2 and 3), the average collection efficiencies based on $\mathrm{SO}_{4}^{2-}$-filter measurements were different: $\mathrm{CE}=1.0$ in Zurich and $\mathrm{CE}=0.5$ in Reiden. In Zurich $\mathrm{PM}_{1}-\mathrm{SO}_{4}^{2-}$ was available, but only the larger size cut $\mathrm{PM}_{10}-\mathrm{SO}_{4}^{2-}$ in Reiden. There are some indications from aerosol mass size distribution that a considerable aerosol mass fraction was in the supermicron mode (representing a size range where the lens transmission efficiency of the AMS instrument is suboptimal; Liu et al., 2007) during this winter episode (Lanz et al., 2008). Thus, it is possible that the different size cuts for the ancillary sulfate filter-measurements have had an influence on the estimated CE in this case, and correspondingly the CE given in Table 2 is $0.5 \ldots 1.0$ rather than 1.0 for Zürich, January 2006.

\subsubsection{Black carbon (BC) measurements}

Black carbon (BC) mass concentrations were determined by an Aethalometer (Magee Scientific, USA, type AE31; also see Sandradewi et al., 2008a) except for Hohenpeissenberg, where $\mathrm{EC}_{2.5}$ measurements were used (see Hock et al., 2008), and for the campaign in the Rhine Valley, where a MAAP (Multi Angle Absorption Photometer 5012, Thermo) was deployed (Weimer et al., 2010).

\subsection{Ion balance calculation}

In order to characterize the neutralization state (ion balance) of an aerosol, the measured ammonium concentration, $\left[\mathrm{NH}_{4}^{+}\right]_{i}$, and a predicted value, $\left[\mathrm{NH}_{4}^{+}\right]_{\mathrm{eq}, i}$, are often compared (e.g., Zhang et al., 2005b, 2007b; Takegawa et al., 2006):

$\left[\mathrm{NH}_{4}^{+}\right]_{i}=a\left[\mathrm{NH}_{4}^{+}\right]_{\mathrm{eq}, i}+b$,

where $\left[\mathrm{NH}_{4}^{+}\right]_{\mathrm{eq}, i}$ represents the concentration of $\mathrm{NH}_{4}^{+}$cations theoretically needed to balance the anions $\mathrm{SO}_{4}^{2-}$, $\mathrm{NO}_{3}^{-}$, and $\mathrm{Cl}^{-}$in each sample $i$. On a molar basis

$m\left(\mathrm{NH}_{4}^{+}\right)=M\left(\mathrm{NH}_{4}^{+}\right)\left(2 n\left(\mathrm{SO}_{4}^{2-}\right)+n\left(\mathrm{NO}_{3}^{-}\right)+n\left(\mathrm{Cl}^{-}\right)\right)$,

where $n$ is the number of moles [1], $m$ is the mass [g], and $M$ is the Molar mass [g/mol]. Equation (2) can be rewritten explicitly:

$$
\begin{aligned}
{\left[\mathrm{NH}_{4}^{+}\right]_{\mathrm{eq}, i} } & =18.04\left(\left(\left[\mathrm{SO}_{4}^{2-}\right] \cdot 2 / 96.06\right)+\left(\left[\mathrm{NO}_{3}^{-}\right] / 62.00\right)\right. \\
& \left.+\left(\left[\mathrm{Cl}^{-}\right] / 35.45\right)\right) .
\end{aligned}
$$

In an ideally balanced case $\left[\mathrm{NH}_{4}^{+}\right]_{i}=\left[\mathrm{NH}_{4}^{+}\right]_{\mathrm{eq}, i}$ and the regression coefficients $a=1$ and $b=0$ in Eq. (1). For the studied submicron non-refractory aerosols we implicitly assumed that $\mathrm{NH}_{4}^{+}$represents the main cation in the aerosol balancing (determined as neq, neq $\left(\mathrm{NH}_{4}^{1+}\right)=1 \cdot\left[\mathrm{NH}_{4}^{+}\right] / M_{\mathrm{NH}_{4}^{+}}$). 
Indeed, it can be calculated from Hueglin et al. (2005) that even in $\mathrm{PM}_{2.5}$ including refractory species the positive ions mainly were represented by $n\left(\mathrm{NH}_{4}^{+}\right)$, making up for about $90 \%$ of the sum of the measured positive ions, i.e. $n\left(\mathrm{NH}_{4}^{+}\right)+n\left(\mathrm{Na}^{+}\right)+2 n\left(\mathrm{Mg}^{2+}\right)+2 n\left(\mathrm{Ca}^{2+}\right)+n\left(\mathrm{~K}^{+}\right)$ (note that several metal salts of $\mathrm{SO}_{4}^{2-}$ and $\mathrm{NO}_{3}^{-}$such as $\mathrm{MgSO}_{4}$ do not evaporate at $600^{\circ} \mathrm{C}$, the temperature of the thermal vaporizer in the AMS instrument, and will therefore negligibly contribute to the AMS- $\mathrm{SO}_{4}^{2-}$ ).

\subsection{Factor analysis}

Factor analysis as used for source apportionment in air quality studies starts with ambient concentrations of pollutants (gases or aerosols) arranged as a matrix, $\mathbf{X}$, dimensions as samples in time (rows) and chemical properties (columns). In the case of AMS data, samples in time are represented by single AMS spectra and chemical properties are mass fragments (e.g., organic mass-to-charge ratios $m / z$ 's $12 \ldots 300$ in this case here). The measurement matrix, $\mathbf{X}\left[\mu \mathrm{g} \mathrm{m}^{-3}\right.$ ], is factorized into two matrices, $\mathbf{G}$ and $\mathbf{F}$ :

$\mathbf{X}=\mathbf{G F}+\mathbf{E}=\widehat{\mathbf{X}}+\mathbf{E}$,

where matrix $\mathbf{F}$ [dimensionless] represents $p$ factor profiles (or "factor loadings", "calculated mass spectra"), while G [ $\mu \mathrm{g} \mathrm{m}^{-3}$ ] contains the $p$ time series of the corresponding factor contributions. The values in $\mathbf{G}$ and $\mathbf{F}$ are estimated based on an uncertainty-weighted least-square algorithm implemented in PMF2, a factor analytical tool by P. Paatero (see Paatero and Tapper, 1993, 1994). In this approach all measured mass spectra $(\mathbf{X})$ are approximated $(\widehat{\mathbf{X}}=\mathbf{G F})$ by linear combinations of factor profiles $(\mathbf{F})$ times their corresponding time series (G) up to some errors, $\mathbf{E}$ (see Eq. 4). The factor profiles, $\mathbf{F}$, can be interpreted as (combinations of) source profiles (e.g., BBOA) or characteristic mass spectra that cannot be directly linked to specific physical emission sources (e.g., OOA, which mostly results from the oxidation and condensation of various gaseous precursors rather than from direct particulate emissions). These factor interpretations were validated by independent studies or data (e.g. by comparing the time series of OOA or SOA retrieved by FA-AMS with the time series of measured secondary inorganics; see Sect. 3 and Supplement, SI). In PMF modeling, typically no further information about the sources/components other than the usual non-negativity of $\mathbf{G}$ and $\mathbf{F}$ are assumed. In contrast, in the ME-2 (Paatero, 1999) based approach used here, $\mathbf{F}$ is partially known and constrained (for details see Lanz et al., 2008). This latter approach has proven to be useful when a factor with a rather well-defined profile or chemical fingerprint (e.g., HOA) is temporally correlated with other factors (showing more spatio-temporal variability in their profiles) and their time series (G) cannot be separated by PMF2. The program PMF2 as applied to AMS organics data has been detailed by Lanz et al. (2007) and Ulbrich et al. (2009).

\section{Results and discussion}

Average AMS-aerosol concentrations for the 13 campaigns in Central Europe are shown in Table 2. These NR-PM concentrations $\left[\mu \mathrm{g} \mathrm{m}^{-3}\right]$ also depend on the assumed collection efficiency (CE) of the AMS instrument (Sect. 2.3.1). Total mass concentrations of NR-PM $\mathrm{PM}_{1}$ typically ranged between 10 and $30 \mu \mathrm{g} \mathrm{m}^{-3}$. Relatively high concentrations can be associated with campaigns that overlapped with periods of strong thermal inversions: the winter campaigns in Reiden $\left(56.6 \mu \mathrm{g} \mathrm{m}^{-3}\right)$ and Payerne $\left(16.2-32.3 \mu \mathrm{g} \mathrm{m}^{-3}\right)$. Lower concentrations were observed at the two remote and elevated sites (Hohenpeissenberg, $6.7 \mu \mathrm{g} \mathrm{m}^{-3}$, and Jungfraujoch, $1.6 \mu \mathrm{g} \mathrm{m}^{-3}$ ). The typical values for NR-PM $\mathrm{PM}_{1}$ reported by Zhang et al. (2007a) were somewhat lower $\left(3-16 \mu \mathrm{g} \mathrm{m}^{-3}\right)$. In this latter overview on the Northern Hemisphere, more campaigns were performed at remote sites, but less winter data were included. For the Central European campaigns, the average for the summer data was lower $\left(8-14 \mu \mathrm{g} \mathrm{m}^{-3}\right)$ than the average for winter data $\left(22-26 \mu \mathrm{g} \mathrm{m}^{-3}\right)$. As an appreciable exception only 4.0-7.9 $\mu \mathrm{g} \mathrm{m}^{-3} \mathrm{NR}-\mathrm{PM}_{1}$ was observed in Massongex (located in a Central Alpine valley) during winter 2006: the comparatively low concentrations could be attributed to the absence of stable temperature inversions and foehn influences (Southern winds, comparatively high temperatures, low relative humidity), which caused precipitation and deposition of air pollutants South of the Alps. The total $\mathrm{PM}_{2.5}$ values found in the overview for Europe (Putaud et al., 2004; Hueglin et al., 2005) were somewhat higher than the NR-PM 1 values reported here, but the former aerosol measurements also included supermicron $\left(\mathrm{PM}_{2.5-1.0}\right)$ and refractory material.

\subsection{Chemical composition of $\mathbf{P M}_{1}$}

\subsubsection{Main NR-PM $\mathrm{M}_{1}$ constituents $\left(\mathrm{OM}, \mathrm{SO}_{4}^{2-}, \mathrm{NO}_{3}^{-}\right.$, and $\mathrm{NH}_{4}^{+}$)}

On the basis of campaign averages, the organic material made up about $33 \%$ to $66 \%$ in NR-PM 1 for the 13 campaigns in Central Europe (Fig. 2). As an exception, more than $80 \%$ OM was found in Roveredo, December 2005, which can be explained by a considerable impact of local wood combustion (Alfarra et al., 2007) as confirmed by radiocarbon $\left({ }^{14} \mathrm{C}\right)$ and multi-wavelength particulate light absorption measurements (Szidat et al., 2007; Sandradewi et al., 2008b). The smallest relative sulfate contribution (3\%) was found at the same site, highlighting a regime of stagnant air with limited influences of regional and aged background air. In contrast, sulfate was most abundant (26\%) in aerosols from the high-alpine background site Jungfraujoch, and aerosols from Hohenpeissenberg showed relatively high sulfate contributions (19\%) as well. Note that the absolute sulfate values (about $1.8 \pm 0.4 \mu \mathrm{g} \mathrm{m}^{-3}$ ) were comparable across Central Europe, indicating that it represents a regional pollutant (in 
the absence of local wood burning; Weimer et al., 2010). It is plausible that sulfate showed relatively high contributions

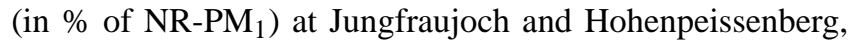
because other main aerosol constituents (OM, nitrate, ammonium) were low due to missing emission sources (e.g., no local biomass burning and little traffic) and are depleted more efficiently during the transport of the air masses from source to receptor. More precisely, ammonium is depleted by wet deposition during transport, without being replenished. Furthermore, $\mathrm{NO}_{\mathrm{x}}$ shows a faster oxidation rate than $\mathrm{SO}_{2}$, resulting in an initially increasing nitrate-to-sulfate ratio close to the sources, which then decreases on further transport (Colbeck, 1998). Thus, sticking to the reasoning by Henning et al. (2003) the equivalent ratio of ammonium to the sum of sulfate and nitrate will decrease during the chemical aging of air masses as soon as there is not enough ammonia left to neutralize the aerosol. This in turn results in a continuous decrease of the nitrate-to-sulfate ratio, since $\mathrm{HNO}_{3}(\mathrm{~g})$ is outgassed under low ammonium conditions (Wexler and Seinfeld, 1990). In the boundary layer, $\mathrm{HNO}_{3}(\mathrm{~g})$ and $\mathrm{NH}_{3}(\mathrm{~g})$ are efficiently depleted by dry deposition, eventually also depleting the particulate ammonium nitrate because of its equilibrium with the former the gas-phase species. Also Putaud et al. (2004) found increasing non-sea salt sulfate contributions in $\mathrm{PM}_{2.5}$ with increasing distances from large pollution sources. However, the sulfate concentrations reported in Putaud et al. (2004) and Hueglin et al. (2005) were consistently higher (typically $2-5 \mu \mathrm{g} \mathrm{m}^{-3}$ ) than the values reported here $\left(\sim 2 \mu \mathrm{g} \mathrm{m}^{-3}\right)$. This difference can be explained by three reasons: (i) a substantial fraction of sulfate mass was found at around $1 \mu \mathrm{m}$ aerodynamic diameter (Putaud et al., 2004), a region with suboptimum lens efficiency of the AMS (Liu et al., 2007). (ii) Decreasing trends in sulfate mass were observed for Europe (decrease by 50-75\% between 1980 and 2000 according to Lövblad et al., 2004). Assuming a lag period of about one decade between this study and the referenced earlier overviews might thus explain a decrease of the sulfate mass by about one third. (iii) The potential refractiveness of sulfates (e.g., $\mathrm{K}_{2} \mathrm{SO}_{4}$, not measured by the AMS) might also cause a minor difference in the observed sulfate mass loadings. The same value for the average sulfate mass loading as calculated here $\left(\sim 2 \mu \mathrm{g} \mathrm{m}^{-3}\right)$ can be derived for North-America and Europe from the worldwide overview by Zhang et al. (2007a; Table SI-2 therein), while markedly higher values are found for Asian sites.

In contrast, $\mathrm{OM}$ (on average $10.0 \pm 1.8 \mu \mathrm{g} \mathrm{m}^{-3}$ ), $\mathrm{NH}_{4}^{+}$ $\left(2.2 \pm 0.6 \mu \mathrm{g} \mathrm{m}^{-3}\right)$, and $\mathrm{NO}_{3}^{-}\left(4.6 \pm 1.5 \mu \mathrm{g} \mathrm{m}^{-3}\right)$ mass concentrations were comparable in this study and Putaud et al. (2005). It is possible that the loss of supermicron mass $\left(\mathrm{PM}_{2.5-1.0}\right)$, which can not be measured by the AMS instruments, was compensated by additional mass coverage of semi-volatile organics and ammonium nitrate, which are potentially lost by using filter-techniques. These two opposing artifacts might have led to comparable mass loadings in that case. The average $\mathrm{OM}, \mathrm{NH}_{4}^{+}$, and $\mathrm{NO}_{3}^{-}$values derived from Zhang et al. (2007a) were clearly lower at about $5.0 \mu \mathrm{g} \mathrm{m}^{-3}, 1.5 \mu \mathrm{g} \mathrm{m}^{-3}$, and $1.3 \mu \mathrm{g} \mathrm{m}^{-3}$, respectively. The discrepancy can be explained by the fact that fewer winter campaigns (mostly linked to higher aerosol concentrations in Central Europe; see above) and more remote/coastal sites (often associated with lower aerosol burdens) were considered in this latter study. In fact, if we average our $\mathrm{OM}, \mathrm{NH}_{4}^{+}$, and $\mathrm{NO}_{3}^{-}$concentrations for summer campaigns only (resulting in mass concentrations of $7.0 \pm 2.2 \mu \mathrm{g} \mathrm{m}^{-3}$, $1.1 \pm 0.3 \mu \mathrm{g} \mathrm{m}^{-3}, 1.3 \pm 0.3 \mu \mathrm{g} \mathrm{m}{ }^{-3}$ respectively) the concentration ranges in the two studies are more similar.

The average chemical composition of NR-PM $\mathrm{PM}_{1}$ was very similar for the different sites in the Swiss Plateau when the campaigns were classified according to the season of the year (Fig. 2). It is important to note that the campaigns in the Swiss Plateau were carried out at sites with rather different characteristics: urban background (Zürich), rural/motorway (Härkingen and Reiden), and rural/agricultural (Payerne). In summer, roughly $66 \%$ of NR-PM 1 was organic and only $33 \%$ inorganic (with comparable contributions from $\mathrm{SO}_{4}^{2-}$, $\mathrm{NH}_{4}^{+}$, and $\mathrm{NO}_{3}^{-}$). In winter, only about $33 \%$ of NR-PM was organic and $\mathrm{NH}_{4}^{+}$plus $\mathrm{NO}_{3}^{-}$was most abundant (about $50 \%$ of NR-PM 1 ). Low temperatures strongly favor the formation of particulate ammonium nitrate $\left(\mathrm{NH}_{4} \mathrm{NO}_{3}\right.$,aer) from its gaseous precursors ammonia $\left(\mathrm{NH}_{3}, \mathrm{~g}\right)$ and nitric acid $\left(\mathrm{HNO}_{3}, \mathrm{~g}\right)$ (Seinfeld and Pandis, 1998).

As for the seasonally grouped campaigns in the Swiss Plateau, relatively similar chemical compositions are obtained for the Alpine sites, when sorted by position of site (and season of the year) (Fig. 2). The two elevated and remote sites of Jungfraujoch and Hohenpeissenberg (May campaigns) showed similar compositions: OM was highest (43\% and 50\%), and $\mathrm{SO}_{4}^{2-}(26 \%$ and $19 \%)$ was more abundant than $\mathrm{NO}_{3}^{-}(18 \%$ and $19 \%)$ and $\mathrm{NH}_{4}^{+}(13 \%$ and $11 \%)$, which has to be attributed to transformation processes occurring during transport of the air masses to Jungfraujoch and Hohenpeissenberg as discussed above. Also a rather similar aerosol composition can be observed for the different Alpine locations at low altitude in winter (showing about 50$60 \% \mathrm{OM}, 5-10 \% \mathrm{SO}_{4}^{2-}, 10-12 \% \mathrm{NH}_{4}^{+}$, and $20-27 \% \mathrm{NO}_{3}^{-}$) with the above mentioned exception of Roveredo, December 2005, where the relative OM contribution exceeded the typical OM fraction at the other sites and was probably mostly due to strong local emissions (residential wood combustion) in combination with stable air masses (thermal inversions) and lack of precipitation.

\subsubsection{Other NR-PM 1 constituents $\left(\mathrm{Cl}^{-}\right.$and PAHs)}

In summer campaigns, the most volatile compound, chloride $\left(\mathrm{Cl}^{-}\right)$, accounted for $<1 \%$ NR-PM 1 on average. At lower temperatures, the equilibrium between $\mathrm{NH}_{3}(\mathrm{~g})$, hydrochloric acid $(\mathrm{HCl}, \mathrm{g})$, and ammonium chloride $\left(\mathrm{NH}_{4} \mathrm{Cl}\right.$,aer) is shifted towards the aerosol-phase and probably explains 


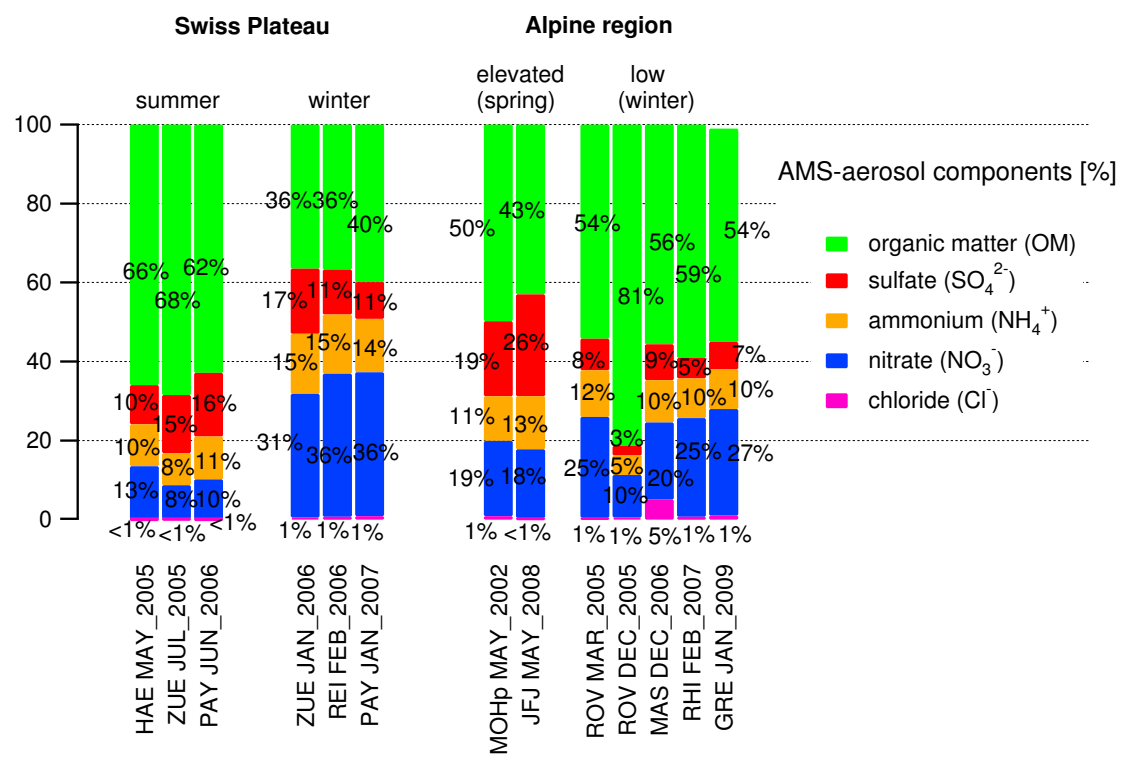

Fig. 2. Relative composition of non-refractory submicron aerosols $\left(\mathrm{NR}-\mathrm{PM}_{1}\right)$ in Central Europe measured by aerosol mass spectrometers (AMS): organic matter $(\mathrm{OM})$, sulfate $\left(\mathrm{SO}_{4}^{2-}\right)$, ammonium $\left(\mathrm{NH}_{4}^{+}\right)$, nitrate $\left(\mathrm{NO}_{3}^{-}\right)$and chloride $\left(\mathrm{Cl}^{-}\right)$. The standard deviation of the relative means $(\%)$ reported here is typically about $1 \%$ or less.

(in analogy to $\mathrm{NO}_{3}^{-}$) the slightly higher contributions of $\mathrm{Cl}^{-}$observed in the winter season (about $1 \%$ ). This seasonal difference in non-refractory chloride fractions (enhanced in winter) has been reported from other continents as well: Japan (Takegawa et al., 2006) and New York City (Drewnick et al., 2004; Weimer et al., 2006). Chloride is unlikely due to de-icing salts because most mass of these particles is found in the super-micron mode and because they are mostly refractory (however, heterogeneous reactions involving $\mathrm{NaCl}(\mathrm{s})$ also need to be considered: $\mathrm{NaCl}(\mathrm{s})+\mathrm{HNO}_{3}(\mathrm{~g}) \longrightarrow \mathrm{NaNO}_{3}(\mathrm{~s})+\mathrm{HCl}(\mathrm{g})$; see Leu et al., 1995). The most abundant chloride fraction ( $\sim 5 \%$ NR-PM $\left.{ }_{1}\right)$ was observed in Massongex, which might be explained by the industrial vicinity $(\mathrm{HCl}, \mathrm{g}$ emissions with availability of $\left.\mathrm{NH}_{3}, \mathrm{~g}\right)$. A comparable chloride fraction $(\sim 4 \%)$ was reported for Tokyo, winter 2004 (Takegawa et al., 2006).

The PAH (polycyclic aromatic hydrocarbons) contributions were typically rather low (at about $0.1 \%$ of OM or less; see Table S2) compared with the other aerosol components discussed above $\left(\mathrm{SO}_{4}^{2-}, \mathrm{NO}_{3}^{-}, \mathrm{Cl}^{-}, \mathrm{NH}_{4}^{+}, \mathrm{OM}\right)$, but higher in winter (Zürich: $0.10 \%$ of OM; Payerne $0.08 \%$ of OM) than in summer (Zürich: $0.03 \%$ of OM; Payerne $0.00 \%$ of OM), indicating that PAH levels are possibly related to the amount of wood burning emissions which are enhanced in winter (see Sect. 3.2.). In addition, enhanced photochemistry in summer leads to faster photochemical degradation of PAHs (Aceves and Grimalt, 1993, Perraudin et al., 2007). Even higher PAH/OM ratios (0.1-0.2\%) were observed for winter campaigns at Alpine locations (e.g. Massongex, Roveredo, and Grenoble). In summer, the highest ratio $(0.12 \%)$ was found for Härkingen, a site near a motorway. Overall, on- road mobile measurements in winter (strong influence of both traffic and wood burning) showed the highest average ratios PAH/OM (namely $\sim 0.3 \%$ ).

\subsubsection{Black carbon (BC)}

Black carbon, BC, or elemental carbon, EC, typically varied between $6-15 \%$ of NR-PM $1+\mathrm{BC}$ (or EC) (i.e., $\mathrm{PM}_{1}$ if one assumes that $\mathrm{BC} / \mathrm{EC}$ makes up for most of the refractory $\mathrm{PM}_{1}$ ). High $\mathrm{BC}$ fractions $(>15 \%$ of NR-PM $1+\mathrm{BC})$ were found for the industrial site of Massongex (18-30\%) and the on-road mobile measurements in the Alpine Rhine Valley $(21-35 \%)$, and relatively low values at the (remote) sites in Payerne (3-6\%), Hohenpeissenberg (4\%), and Jungfraujoch $(7 \%)$ (Table 2). In contrast to the NR-PM 1 measurements (AMS), BC was determined by different types of instruments: for the majority of the campaigns $\mathrm{BC}$ was determined by online aethalometry with the exception of Hohenpeissenberg (EC measurements) and the Rhine Valley (MAAP). The lowest BC fraction was found at Hohenpeissenberg (4\%), but it should be noted that thermochemical techniques as used for that latter site potentially underestimate $\mathrm{BC}$ mass compared to aethalometry (Hitzenberger et al., 2006). Contrarily, according to the study by Hitzenberger et al. MAAP measurements were in relatively good agreement with aethalometry, at least at such high concentrations as found during the mobile campaigns $\left(7 \mu \mathrm{g} \mathrm{m}^{-3}\right)$. Note that Hueglin et al. (2005) reported EC mass contributions to $\mathrm{PM}_{2.5}$ of about $5 \%, 10 \%$ and up to $20 \%$ for rural/elevated sites, urban background/near-city sites, and kerbsides, respectively. 


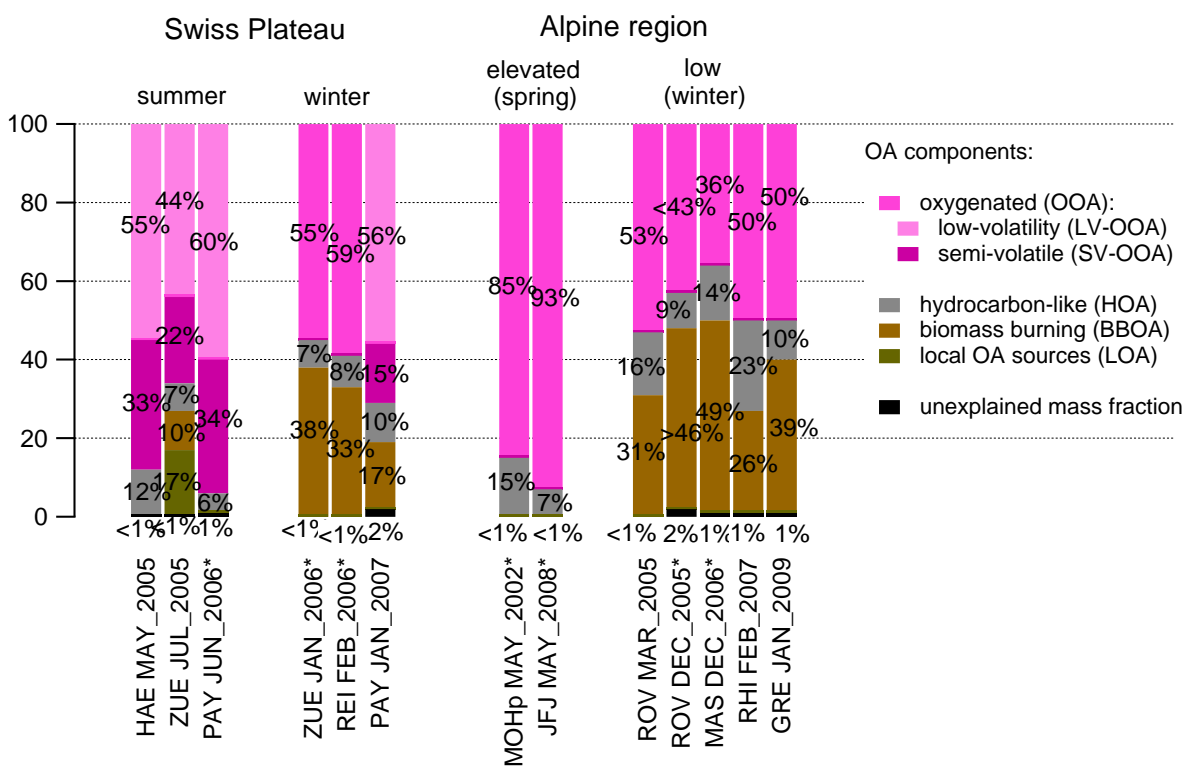

Fig. 3. Relative composition of the organic matter (OM, determined by the AMS instrument): OOA, HOA, BBOA, and local OA (LOA) as determined by factor analysis on organic mass spectra (see Sects. 2.5 and 3.2 for details). The standard deviation of the relative means (\%) reported here is typically about $1 \%$ or less. The retrievability of the PMF-AMS method ( 5\% OA) and different levels of uncertainties (e.g. number of factors or rotations), however, were found to be often larger than the standard deviations of the resulting OA components (Lanz et al., 2007, 2008; Ulbrich et al., 2009; Allan et al., 2010). In Roveredo, November 2005, a primary wood burning contribution is possibly present in the OOA-factor $(\mathrm{m} / \mathrm{z} 60$ is at about $1 \%$ in this latter factor) and, therefore, total BBOA is expected to be higher (" $>46 \%$ ") and SOA (OOA) lower ("<43\%") than the averages of the corresponding factors. * = FA results based on a ME-2 analysis (for details see SI section).

\subsubsection{Ion balance}

Despite the large variability in the inorganic components the ion balance was overall neutral $(a=0.99 \pm 0.03$ in Eq. (1) including all the $n=13$ campaigns), leading to the hypothesis that there is usually enough ammonia $\left(\mathrm{NH}_{3}, \mathrm{~g}\right)$ available to neutralize the $\mathrm{SO}_{4}^{2-}, \mathrm{NO}_{3}^{-}$, and $\mathrm{Cl}^{-}$anions in Central Europe. As an exception, low aerosol loadings at the Jungfraujoch (which can be indicative of free tropospheric and long-range transported aerosol) coincided with an $\mathrm{NH}_{4}^{+}$deficiency according to Eq. (1) and thus potentially represent acidic aerosols. However, the $\mathrm{NH}_{4}^{+}$-concentrations at the Jungfraujoch were often close to the detection limit (see Drewnick et al., 2009) such that this latter trend can not be fully confirmed from this AMS data set. Cozic et al. (2008) have shown based on a 6-year data set of filter measurements that with decreasing aerosol concentration a lower degree of neutralization is generally achieved (which is in line with the above discussion on transformation processes during aging). Thus, we can not rule out that there are no episodes of acidic aerosol over Central Europe. A general aerosol neutralization can also be derived from Hueglin et al. (2005; Tables 3 and 4 therein) for $\mathrm{PM}_{2.5}$ (yearly averages) in Swiss cities (Basel, Bern, and Zürich) and one site in the Jura mountains (Chaumont). This is different for coastal/marine sites, where the amount of $\mathrm{NH}_{4}^{+}$often cannot balance the negative ions (as can be derived from Putaud et al., 2004 and Zhang et al., 2007a) and suggests that at such sites tropospheric aerosols as well can be acidic.

\subsection{Organic components and OA sources}

The organic subfractions discussed here were identified and quantified as described in Sect. 2.5 and references therein. Figure 3 shows the relative composition of the main OA components: OOA (oxygenated organic aerosol), HOA (hydrocarbon-like organic aerosol), BBOA (biomass burning organic aerosol), and organic aerosols from local sources (Zürich, summer 2005: charbroiling and a minor source, potentially representing food cooking).

OOA (oxygenated organic aerosol, mostly interpreted as secondary OA, SOA) was typically the most abundant organic component, ranging from $36 \%$ of OM (in an industrialized Alpine valley in winter; Massongex) up to $>80 \%$ of OM at rural and remote sites (Jungfraujoch, Hohenpeissenberg, Härkingen and Payerne in summer) (Fig. 3). Generally, the ubiquity and dominance of OOA found here are in good agreement with the findings by Zhang et al. (2007a). However, in Alpine valleys in wintertime OOA contributions to OA can be relatively low $(<50 \%)$ due to strong local influences of wood burning (BBOA) and traffic (HOA): as an example, also in Roveredo (campaign in December 2005 
with large primary wood burning emissions; see Sect. 3.1.1), OOA was comparatively low $(<43 \%)$. Concerning maximum OOA/OA ratios, note that the Jungfraujoch represents a site intermittently advected from the free tropospheric air as well as air from the polluted boundary layer (PBL) (Lugauer et al., 2000): for periods with exclusively free tropospheric air (or highly processed PBL air), the $m / z 57$ fragment can be completely depleted (accordingly, HOA can not be retrieved) at the Jungfraujoch and OOA then accounts for nearly $100 \%$ of OM in such situations (which was actually the case for the Jungfraujoch campaign in 2002 analyzed by Zhang et al., 2007a; see Fig. 2 therein).

The relative abundance of the different organic components (OOA, HOA, BBOA) was similar at the different Swiss Plateau sites (Payerne, Zürich, Härkingen, and Reiden) when the campaigns were grouped by season of the year (Fig. 3) (as was observed for the total AMS-aerosol composition; Fig. 2). However, in Zürich (summer 2005) additional, local POA sources could be identified (wood burning, charbroiling, and potentially food cooking, which was identified as a relevant POA source in London and Manchester as well, Allan et al., 2010), but not in the summer campaigns in Härkingen (rural-motorway) and Payerne (rural-agricultural). The OA components at these latter two stations (Härkingen and Payerne) were similar: $65 \%$ and $60 \%$ LV-OOA, $33 \%$ and $34 \%$ SV-OOA, and $12 \%$ and $6 \%$ HOA respectively. In winter, primary organics (approximated by the sum BBOA + HOA) were somewhat lower ( 27\% OA) at the remote site Payerne (due to its distance to major combustive aerosol sources) than for Zürich (urban site) and Reiden (near motorway), showing primary OA fractions of $45 \%$ and $41 \%$, respectively. The relative contribution of OA components for the two latter stations (Zürich and Reiden) was comparable (55\% and 59\% OOA, $7 \%$ and $8 \% \mathrm{HOA}$, and $38 \%$ and $33 \%$ BBOA, respectively). Further note that also Zürich (located in the Swiss Plateau) and Grenoble (Alpine site) both representing urban background sites showed similar OA compositions in wintertime (Fig. 3), in particular high BBOA contributions were observed $(\sim 40 \%$ OA).

\section{Oxygenated organic aerosol (OOA) and its subtypes}

The separation of OOA into low-volatility OOA, LV-OOA, and semi-volatile OOA, SV-OOA (more descriptive nomenclature according to Jimenez et al., 2009, for the components formerly called OOA1 and OOA2, respectively; see Lanz et al., 2007), could be observed for all summer campaigns (Fig. 3). A literature survey of PMF applications on organic AMS data suggests that this observation is also valid for North-America (Cotrell et al., 2007; Nemitz et al., 2008; Docherty et al., 2008; Aiken et al., 2008; Ulbrich et al., 2009; DeCarlo et al., 2010). PMF-AMS studies for other parts of the world (see above) typically focused on summer campaigns. As an exception, Slowik et al. (2009) studied an AMS winter campaign in Toronto and Allan et al. (2010) three winter campaigns in Manchester and London, UK; no separation of OOA into a low-volatility and a semi-volatile fraction was observed for these data based on the PMF-AMS analysis. It was described in detail that LV-OOA follows the time trends of sulfate and oxidant gases (odd oxygen, $\mathrm{O}_{3}+$ $\mathrm{NO}_{2}$ ), i.e., they exhibit a regional build-up in the afternoon (Lanz et al., 2007; Herndorn et al., 2008) and SV-OOA may trace the nitrate series (condensation during the night and reevaporation during the day, effecting more diurnal variation than for LV-OOA) (Lanz et al., 2007; Ulbrich et al., 2009). In winter, the lower temperature and the smaller (diurnal) temperature ranges might explain the lower OOA variability (and the same reasoning would explain the fact that OOA did not separate into different OOAs at the Jungfraujoch). Note that during the Payerne campaign in winter, for which LV- and SV-OOA could be differentiated, a temperature range of $\Delta T$ $\left(T_{\max }-T_{\min }\right)=26{ }^{\circ} \mathrm{C}$ (and diurnal differences $>10^{\circ} \mathrm{C}$ ) was observed, which is similar to the one observed for the Zürich summer campaign $\left(\Delta T=25^{\circ} \mathrm{C}\right.$; diurnal differences $\left.>10^{\circ} \mathrm{C}\right)$.

The OOA component had a strong temporal correlation with ammonium, ranging between $R^{2}=0.53$ (coefficient of determination) for Massongex and $R^{2}=0.86$ for Grenoble (see Table S1) and were similarly correlated with the sum $\mathrm{SO}_{4}^{2-}+\mathrm{NO}_{3}^{-}$. The latter behavior is to be expected as the concentration of $\mathrm{NH}_{4}^{+}$is highly correlated with the sum of $\mathrm{SO}_{4}^{2-}$ and $\mathrm{NO}_{3}^{-}\left(R^{2}\right.$ is typically $\left.0.8-0.9\right)$. The time series of LV-OOA were typically correlated with sulfate $\left(R^{2}=0.41 \ldots 0.54\right)$, while SV-OOA could be related to nitrate showing episodically linear correlations: e.g., for four fifths of the Zürich, summer campaign $\left(R^{2}=0.55\right)$, or for the last third of the campaign in Payerne, June $2006\left(R^{2}=0.67\right)$. The strong correlation with secondary inorganics found here further supports previous evidence that OOA is mainly secondary in its origin (Zhang et al., 2005a, 2007a; Lanz et al., 2007, 2008; Ulbrich et al., 2009). However, also primary OA from wood fire emissions may be characterized by an OOAlike signature, depending on burning conditions (Weimer et al., 2008; see Sect. 3.2.2), representing one of several reasons why no perfect correlation between OOA and secondary inorganics can be expected and a portion of OOA may represent fresh wood combustion OA.

\section{Primary organic aerosol (POA)}

Hydrocarbon-like organic aerosol (HOA) was typically between $6-16 \%$ of OA, but enhanced contributions were found for on-road mobile measurements in the Alpine Rhine Valley (23\% on average). The HOA component contributed to OA in all campaigns, but in about half of the cases (see SI section) a measured HOA-profile from the literature (Canagaratna et al., 2004; Schneider et al., 2006) had to be imposed on the data to separate its contribution from temporally correlated BBOA or OOA series (details see Lanz et al., 2008). Compared to the Swiss (remote) sites Jungfraujoch and Payerne, relatively high HOA contributions were 
observed in Hohenpeissenberg, Germany ( $15 \%$ OA), and a similar HOA fraction $(\sim 20 \%$ OA) was identified by the multiple component analysis (MCA) for this latter campaign (Zhang et al., 2007a; Hock et al., 2008). There is a multitude of potential reasons to explain the relatively high HOA fraction at Hohenpeissenberg, Germany (compared to Swiss remote-rural sites): (i) a nearby railway with trains powered by diesel locomotives, (ii) its vicinity to a large city (Munich), (iii) electricity production by fossil-fuels has a prominent role in Germany/Eastern Europe, whereas in Switzerland it is solely produced by hydro and nuclear power (IEA, 2008), and (iv) higher share of diesel cars in Germany (due to lower diesel taxes and prices). Also note that Mohr et al. (2010) found lower HOA/OA ratios on Swiss roads compared to Austrian roads and hypothesized that this could be due the smaller number of heavy-duty diesel vehicles and to the comparatively low share of diesel powered passenger cars in Switzerland ( 10\%; HBEFA, 2004) compared to Austria (60\%; Umweltbundesamt, 2007).

About $26-49 \%$ of OA was attributed to biomass burning OA (BBOA) for lower Alpine sites (all of them can be classified as winter campaigns). For the winter campaigns conducted in the Swiss Plateau, this fraction was typically lower (17-38\%). Concerning the very high BBOA fractions in the Alpine valleys and comparatively lower fraction in the Swiss Plateau we hypothesize the following: stable thermal inversions, smog, low temperatures, and reduced sunlight inhibit local SOA formation and favor the accumulation of locally emitted POA. OOA is a partly regional pollutant and the thermal inversions may trap the air in narrow Alpine valleys even more than at the sites belonging to the Swiss Plateau. BBOA in contrast is assumed to be more locally emitted and less diluted in the shallow PBL of Alpine valleys. Wood burning OA (BBOA) could not be resolved for the high- and pre-alpine background stations (Jungfraujoch and Hohenpeissenberg, respectively), which might be explained by the season (limited residential wood burning and only a few open fires can be expected in spring). Furthermore, primary BBOA is semi-volatile (Lipsky and Robinson, 2006) and might have evaporated and/or oxidized (Capes et al., 2008) during transport to these remote sites - but also for the campaigns in the Swiss Plateau in summer, only a small BBOA fraction ( $\sim 10 \%$ OA) could be observed in Zürich exclusively, potentially emitted from local open fires.

The wood burning component identified by FA-AMS (BBOA) had a consistently higher correlation with $\mathrm{CO}$ $\left(R^{2}=0.38 \ldots 0.78\right)$ than with $\mathrm{NO}_{\mathrm{x}}\left(R^{2}=0.11 \ldots 0.72\right)$ for all campaigns. The correlation of the BBOA time series with $\mathrm{CO}$ and the presence of levoglucosan marker fragments $(\mathrm{m} / \mathrm{z}$ 's 60 and 73$)$ in the BBOA profile indicate its primary origin. However, secondary organic aerosol (SOA) may be rapidly formed from wood burning exhaust (as an example, the formation of SOA from wood-burning related VOCs doubled the total OA amount after a few hours of reactions in the smog chamber according to Grieshop et al., 2009). There- fore, a fraction of SOA from VOCs emitted by wood combustion may show a similar temporal variability (considering several-weeks long measurement campaigns) as the primary BBOA fraction and will be assigned to the same PMF-factor. It is hence possible that a certain fraction of BBOA represents in fact secondarily formed matter (i.e., formed via the oxidation of gas-phase species). The relatively high fraction of organic $\mathrm{m} / \mathrm{z} 44$ in the BBOA factor profiles (up to 5\%; see supplementary information) however could point to both primary (Weimer et al., 2008) and secondary wood burning aerosol (Grieshop et al., 2009); the exact amount of secondary wood burning-aerosol in the BBOA-factor can not be quantified with unit mass resolution at present. BBOAfactors in the present datasets, however, were identified by PMF due to their unique temporal variability, especially due to their enhanced concentrations in the late evening/night, when photochemical SOA production is at a minimum and is not very likely to have a major impact on BBOA.

On the other hand, primary HOA had a stronger correlation with $\mathrm{NO}_{\mathrm{x}}$ compared to BBOA. These latter findings support the results from previous publications (Lanz et al., 2007, 2008; Allan et al., 2010) that HOA is most strongly connected with primary traffic emissions, while the correlation of BBOA with $\mathrm{CO}$ supports its origin from wood burning emissions. However, non-linearities (e.g., as found in the relation SV-OOA vs. nitrate) suggest that these $R^{2}$ 's can only serve as an approximate measure of similarity between the time series and, furthermore, variable emission ratios, removal processes, and reactivity of $\mathrm{CO}, \mathrm{NO}_{\mathrm{x}}$ and $\mathrm{OA}$ need to be considered: at the remote sites of Jungfraujoch and Hohenpeissenberg, e.g., HOA was very weakly correlated with reactive $\mathrm{NO}_{\mathrm{x}}\left(R^{2}<0.10\right)$, but better with the more stable $\mathrm{CO}$ $\left(R^{2}=0.15\right.$ and $R^{2}=0.31$, respectively).

\subsubsection{Organic components and spectral tracers}

In the past, several papers have made use of specific mass fragments as tracers for different aerosol sources. Figure 4 shows the relation between organic mass spectral tracers (measured $\mathrm{m} / \mathrm{z}$ 's 44,57 , and 60) and OOA, HOA, and BBOA as estimated by FA-AMS for all 13 campaigns. Mass fragment $m / z$ 44 is a proxy for oxygenated/secondary OA (Alfarra, 2004; Zhang et al., 2005a), $\mathrm{m} / \mathrm{z} 57$ traces freshly emitted anthropogenic OA (Alfarra, 2004; Zhang et al., 2005a), and $m / z 60$ more specifically indicates time trends of primary biomass burning OA (Schneider et al., 2006; Alfarra et al., 2007). The strongest correlation $\left(R^{2}=0.68, n=13\right)$ was found for organic $m / z 44$ and OOA (or $\Sigma$ 'LV-OOA'+'SV-OOA') normalized to total OA (Fig. 4). An even stronger correlation $\left(R^{2}=0.83, n=11\right.$, not shown) resulted when winter campaigns with relatively low OOA fractions $(\mathrm{OOA} / \mathrm{OA} \leq 40 \%)$ but high BBOA fractions were excluded from these calculations, because a certain but not exactly known amount of organic $\mathrm{m} / \mathrm{z}, 44$ needs to be attributed to primary wood combustion in these cases (Weimer et al., 2008). 

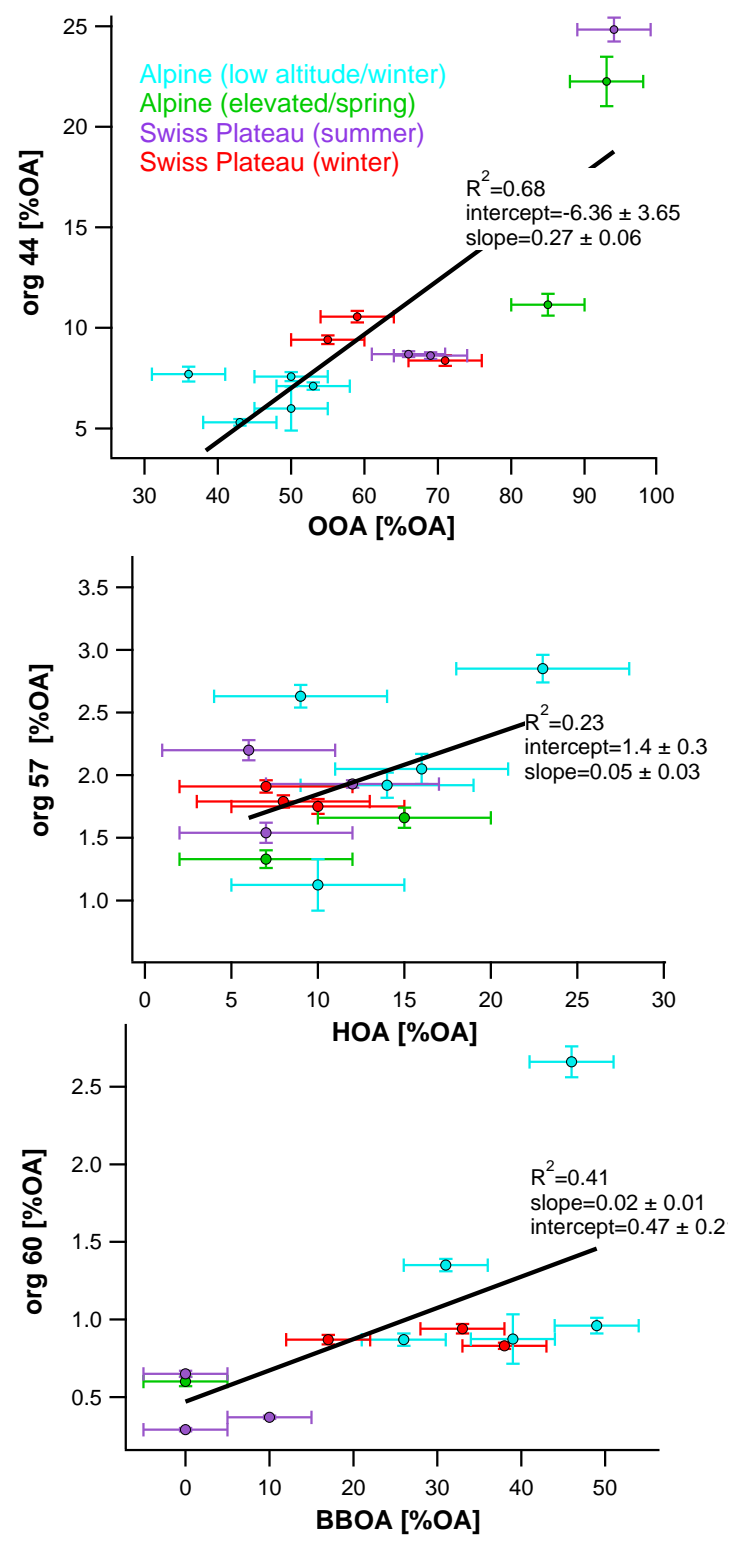

Fig. 4. Relation between organic $m / z$ 's $44,57,60$ (measured) and OOA, HOA, and BBOA (retrieved by FA-AMS) (see Sect. 3.2). Results were normalized by OA (measured). Slope and intercept (orthogonal regression) are represented by solid black lines. The vertical bars represent the standard deviations of the mean ratios organic $m / z, i(i=44,57,60)$ divided by OA, $(\mathrm{m} / z i) /(\mathrm{OA})$, $\sqrt{\text { sd.mean }\left(m / z_{i}\right)^{2}+\text { sd.mean }(\mathrm{OA})^{2}}$. The horizontal bars represent an assumed $\pm 5 \%$ absolute uncertainty for the OA components (see caption of Fig. 3). OOA represents SV-OOA plus LV-OOA. BBOA was set to $0 \%$ in data sets where it could not be identified by means of FA-AMS.

Organic $m / z, 60$ mostly represents fragments from the ionization of levoglucosan (Alfarra et al., 2007) and similar molecules found in smoke from incomplete wood pyrolysis. Organic $m / z 60$ correlates well $\left(R^{2}=0.41\right)$ with BBOA (normalized by OA). However, the organic mass fragment $\mathrm{m} / \mathrm{z}, 60$ is not completely unique to fire emissions (DeCarlo et al., 2008) and $m / z 60\left(\mathrm{C}_{2} \mathrm{H}_{4} \mathrm{O}_{2}^{+}\right)$might also represent organic acids, which can be emitted primarily as well as formed through secondary processes. In the absence of biomass burning DeCarlo et al. (2008) found $\mathrm{m} / \mathrm{z} 60$ to be about $0.3 \%$ of $\mathrm{OA}$ - a similar value can be derived here $(0.26-0.68 \%)$, representing the intercept (at $\mathrm{BBOA}=0$ ) in the plot organic $\mathrm{m} / \mathrm{z}$ 60/OA vs. B̈BOA/OA (Fig. 4).

Lastly, HOA/OA versus organic $\mathrm{m} / \mathrm{z}$ 57/OA shows the weakest correlation $\left(R^{2}=0.23\right)$, and this is plausible due to the following circumstances: the two main fragments at $\mathrm{m} / \mathrm{z}$ $57\left(\mathrm{C}_{4} \mathrm{H}_{9}^{+}, \mathrm{C}_{3} \mathrm{H}_{5} \mathrm{O}^{+}\right)$represent different sources and processes and the relative proportion of these two ions change with chemical processing (Chirico et al., 2010). Organic $\mathrm{m} / \mathrm{z} 57$ is part of wood burning emissions as well and the HOA/OA-range covered by Central European data sets is rather small (usually 6-16\%), whereas in other parts of the Northern Hemisphere, HOA accounts for $~ 37 \%$ in urban OA (Zhang et al., 2007a).

\subsubsection{Mass spectral characteristics of organic components}

The mass spectra of the organic components for Zürich, summer (Lanz et al., 2007), Zürich, winter (Lanz et al., 2008), Grenoble (Favez et al., 2010), Massongex (Perron et al., 2010), and the Rhine Valley (Mohr et al., 2010) were/will be published and discussed separately. The mass spectra of all OA components from all campaigns investigated in this study can be found as supplementary material and on the AMS Spectral Database at http://cires.colorado. edu/jimenez-group/AMSsd/. A detailed discussion by $\mathrm{Ng}$ et al. (2010) also covers the OOA spectra reported here.

Whilst the OOA mass spectra were very similar to each other and to measured reference spectra (typically showing coefficients of determination, $R^{2}$ 's, between 0.90 and 1.00), the primary wood burning spectra were less similar $\left(R^{2}\right.$ 's between 0.80 and 0.90$)$ to each other and external references (which can be downloaded from the mass spectral database; Ulbrich et al., 2009). This latter observation is not very surprising when we consider the widely differing mass spectra of primary wood burning OA resulting at different burning conditions (Weimer et al., 2008). On the other hand, Jimenez et al. (2009) pointed out that OA from a variety of sources will eventually converge to chemically similar, highly aged, and secondary OOA components. Concerning the inter-comparison of HOA-profiles we note those spectra were most similar and typically exhibited $R^{2}$ 's from 0.95 to 1.00 to each other. However, in half of the data cases the HOA-profiles were imposed and their approximate shapes were prescribed (see also Sect. 2.5).

Furthermore, the fraction of mass spectral tracers (organic $\mathrm{m} / \mathrm{z}$ 's 44, 57, 60; see Sect. 3.2.1) within the OA components (HOA, OOA, BBOA) as retrieved by FA-AMS was 
investigated. (The abundance of the key fragments in average OA mass spectra was discussed above). The PMF2/ME2 profiles for the presented data sets were usually relatively similar, e.g. organic $\mathrm{m} / \mathrm{z}, 60$ as the key fragment for wood burning accounted for $2-3 \%$ in BBOA (with the exception of $1 \%$ in Zürich, winter, and $4 \%$ in Roveredo, winter), and organic $m / z 57$ accounted for 6-9\% in HOA at all locations (but $10 \%$ and $18 \%$ in Zürich winter and summer, respectively).

However, there was a considerable variability in the organic $m / z 44$ as a part of OOA (9-21\%) - and LV- and SVOOA even represent two separate populations with respect to their $\mathrm{m} / \mathrm{z}$ 44-content, which was $13-20 \%$ for LV-OOA and $\leq 8 \%$ for SV-OOA spectra. Photochemical aging of the air masses increases the organic $\mathrm{m} / \mathrm{z}$,4-to-OA ratio (Alfarra et al., 2006; Duplissy et al., 2008). A high organic $\mathrm{m} / \mathrm{z}$ 44-toorganics ratio could be linked to high oxygen content $(\mathrm{O} / \mathrm{C}$ atomic ratio, Aiken et al., 2008) and low volatility (Huffman et al., 2009). It therefore can be expected that LV-OOA is enriched with organic $\mathrm{m} / \mathrm{z} 44$, whereas SV-OOA consequently should be depleted in that latter fragment.

The OOA component typically did not separate into SVOOA and LV-OOA for the winter campaigns. We would explain this behavior as follows: the semi-volatile OOA fraction that readily condenses and re-evaporates in summer is more likely to stay in the condensed phase in winter (due to lower temperatures, smaller temperature ranges, and higher OA concentrations). In the cold season its temporal variability is therefore similar to LV-OOA and the two OOA components can not be resolved by PMF. That is not to say that LV-OOA was not present in winter - rather it is not possible to distinguish it from the more volatile material by PMF and all the OOAs are represented by one single PMFfactor. The mass spectra of OOA that did not separate into a semi-volatile and a low-volatility fraction typically resembled more LV-OOA than SV-OOA mass spectra. As an example, the fraction of organic $m / z 44, f_{44}$, in OOA was on average $f_{44}=14 \%$. For the LV-OOA this value was $f_{44}=17 \%$, but only $f_{44}=4 \%$ for SV-OOA. In this sense OOA was in between SV-OOA and LV-OOA, but closer to LV-OOA than to SV-OOA. On the one hand, in winter also less-oxidized (more volatile) compounds are expected to partition into the aerosol compared to summer as a result of the lower temperatures (and higher OA concentrations). Following this reasoning, one would also expect that OOA in winter resembles more SV-OOA than LV-OOA. On the other hand, even if more material with a lower oxidation state partitioned into the aerosol in winter, there could still be a highly stable and highly aged OOA fraction (considering the long periods without wet deposition that may occur in winter, yielding sufficient reaction time to form an LV-type OOA). The high $f_{44}$ in this background OOA (showing the LV-OOA signature) will compensate the less oxidized, low $f_{44}$-material in the single OOA-factors calculated for the winter campaigns. We furthermore hypothesize that SVOCs from wood burning emissions (with a relatively high $\mathrm{O} / \mathrm{C}$ ratio) need a shorter time than other primary SVOCs (with lower O/C ratios) to be aged and evolve towards an LV-OOA type aerosol. More generally, the importance of OA precursors are seasonally different and the oxidation time needed in summer and winter to form LV-type OOA is a matter of future research. Also the different pathways and oxidation agents might be important: OOA may be mainly formed via $\mathrm{O}_{3}$ and $\mathrm{NO}_{3}$ in winter, but more prominently via $\mathrm{OH}$ in summer.

Primary OOA-like emissions from wood burning were reported by Weimer et al. (2008): these OOA-components did not show an obvious increase in the wood burning markers $\mathrm{m} / \mathrm{z}$ 's 60 and 73 (their fraction in the mass spectra of freshly emitted wood burning OA were as low as $0.3 \%$ ). The depletion of mass fragments 60 and 73 can be explained by combustion conditions, at which levoglucosan is pyrolized. Such mass spectra from primary OOA-like wood burning are difficult to distinguish from mass spectra of secondarily formed OOA. However, as OOA was correlated well with secondary inorganics and rather poorly with tracers of primary combustion $\left(\mathrm{CO}, \mathrm{NO}_{\mathrm{x}}\right)$ it can be assumed that this type of interference (i.e., the misclassification of a primary OOA from wood burning as secondary OOA) was of minor importance here. In OOA spectra found for sites with a strong wood burning influence, organic $\mathrm{m} / z$ 's 60 typically was $<1 \%$. The campaign in Roveredo, December 2005, represents an exception in this respect (as mentioned in the caption of Fig. 3), where organic $m / z 60$ was about $1.2 \%$ of OOA.

\subsubsection{Diurnal variability of organic components (OOA, HOA, BBOA)}

The daily cycles for the FA-AMS retrieved organic components are shown in Fig. 5 for Zürich, summer (urban), Hohenpeissenberg (pre-alpine/at the foothills of the Alps) and Jungfraujoch (high-alpine).

The HOA/OA cycle at the urban site (represented by Zürich, summer) shows a bimodal pattern with increases at 06:00-09:00 a.m. (local time) and at 08:00-10:00 p.m. again. By contrast in the urban winter (see Lanz et al., 2008; Zürich), the first HOA/OA peak was observed later (09:0012:00 a.m.) and the second peak earlier (05:00-08:00 p.m.): planetary boundary layer height (delayed down-mixing of aged OOA) and changed emissions patterns (daylight depending activities start later and stop earlier) can account for these shifts. Similar diurnal patterns were observed in Grenoble during the winter season. An HOA/OA behavior as found at the urban background site can be observed for sites near motorways as well (Härkingen, Reiden, and Roveredo). This HOA/OA cycle however was less pronounced at remote sites (represented here in Fig. 5 by Hohenpeissenberg and a comparable pattern was found e.g. for Payerne) and was almost constant for the high-alpine site Jungfraujoch.

The OOA/OA cycle in Zürich (summer campaign) was approximately inverse to HOA/OA (i.e., including dips in the morning at 06:00-09:00 a.m. and in the evening at 

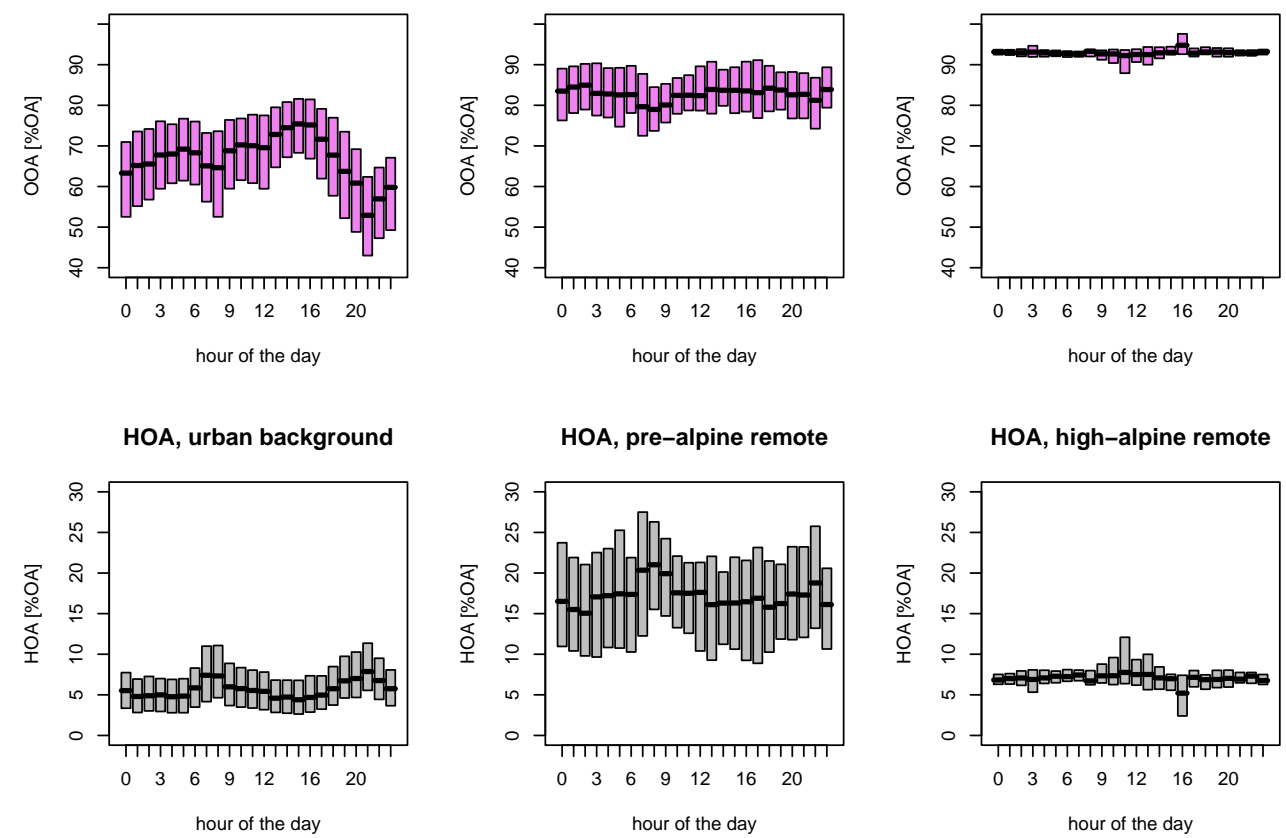

Fig. 5. Daily cycles for OOA/OA (top) and HOA/OA (bottom) (the median values per hour are represented by bold horizontal bars, the 1 st and 3rd quartile of the observations by the boxes) for a site close to anthropogenic OM emissions (left; urban background in Zürich, summer), a remote pre-alpine (at the foothills of the Alps) site (Hohenpeissenberg; middle) and the remote high-alpine station Jungfraujoch (right).

08:00-10:00 p.m., and an increase during the after-noon due to photochemical production of secondary OOA). These typical daily patterns for the urban HOA (traffic-related) and OOA (photochemically produced) have also been reported for several other cities, e.g. in New York (Drewnick et al., 2004). As for HOA/OA, the daily cycles of the OOA/OA ratios level off for stations more distant to emission sources, as shown in Fig. 5 for Hohenpeissenberg and Jungfraujoch.

BBOA/OA cycles in winter (not shown here) were generally similar to HOA/OA, but the evening peaks were found to be typically higher than the corresponding BBOA peaks in the morning and occurring later than the HOA evening-peaks (Lanz et al., 2008; also see Sandradewi et al., 2008). Food cooking aerosols showed peaks at mealtimes (at noon and in the evening; Lanz et al., 2007; Allan et al., 2010).

\section{Conclusions}

Ambient aerosols (NR-PM $)_{1}$ were analyzed at ten locations with widely different characteristics: urban to rural sites, background and kerbside locations, low altitude ( $\sim 200 \mathrm{~m}$ a.s.l.) to elevated sites ( $\sim 3600 \mathrm{~m}$ a.s.l.). Summer as well as winter campaigns were investigated in balanced numbers. Regarding the averages from 13 campaigns, typical NR-PM ${ }_{1}$ concentrations ranged between 10 and $30 \mu \mathrm{g} \mathrm{m}^{-3}$. Campaigns that included periods of persistent thermal inversions in wintertime represent the upper concentration range (up to $\sim 60 \mu \mathrm{g} \mathrm{m}^{-3}$ at the kerbside in Reiden), whereas relatively low values were found for elevated sites in spring ( $\sim 2 \mu \mathrm{g} \mathrm{m}^{-3}$ at the high-alpine site Jungfraujoch).

Overall consistent and - when grouped by season of the year and type of site - rather similar aerosol chemical composition and OA fractions resulted from 13 campaigns performed by different groups and by using different types of AMS instruments. The organic fraction was most abundant in NR-PM - and within the organics the OOA prevailed (determined by factor analysis on aerosol mass spectral data, FA-AMS). This main result is in good agreement with Zhang et al. (2007a). In Alpine valleys in winter, however, organic concentrations were strongly influenced by BBOA, mostly primary wood burning emissions (26-49\% of OA); and most of the OOA component could be attributed to nonfossil sources (as resulted from combinations of FA-AMS and radiocarbon analysis, Prévôt et al., 2010). First but exemplary evidence for an appreciable amount of BBOA in ambient OA was provided by Alfarra et al. (2007) for the alpine-village of Roveredo and by Lanz et al. (2008) for an urban background site. In this study, BBOA was identified and quantified by factor analysis for several more sites: at a rural-agricultural (Payerne), a rural-kerbside (Reiden), a rural-industrial (Massongex), and an urban background site in France (Grenoble). We conclude here from AMS measurements and factor analytical modeling that biomass burning (or more specifically wood combustion) is a seasonally important PM source in Central Europe (Alpine region). The 
strong influence of wood burning on ambient aerosol mass in the Alpine region found here is in line with analyses based on molecular markers (e.g., levoglucosan; Caseiro et al., 2009), multi-wavelength light absorption measurement analysis (Sandradewi et al., 2008a) or radiocarbon analysis (Szidat et al., 2007) and has also been shown for urban areas in Scandinavia (Glasius et al., 2006; Hedberg et al., 2006; Yttri et al., 2009), Ghent, Belgium (Zdráhal et al., 2002) or Paris, France (Favez et al., 2009).

With respect to the inorganic aerosol fractions, a large variation was observed for $\mathrm{SO}_{4}^{2-}\left(3-26 \% \mathrm{NR}-\mathrm{PM}_{1}\right), \mathrm{NO}_{3}^{-}$ (8-36\%), and $\mathrm{Cl}^{-}(0-5 \%)$, and somewhat less variability for $\mathrm{NH}_{4}^{+}(5-15 \%)$, which on average fully neutralized the former anions for all studied campaigns in Central Europe. This large variability, again, could be markedly reduced when the campaigns were grouped by season of the year and location of the site. As an example, the variability in sulfate contributions (overall ranging from 3-26\% of NR-PM ${ }_{1}$ ) only varied between 10-16\% for the Swiss Plateau site in summer, 11$17 \%$ for the Swiss Plateau sites in winter, $19-26 \%$ for the elevated Alpine sites in spring, and 3-9\% for the Alpine sites at low altitude in winter (see Fig. 2).

The following conclusions and hypotheses can be derived from the present study:

- As a main conclusion time of the year (summer vs. winter) and location of the site (Alpine valleys, elevated sites in the Alps, or Plateau sites) were more helpful in explaining the variability in NR-PM 1 composition in Central Europe than e.g. type of the site (urban background, rural, remote etc.). In other words, the relative chemical composition of the organic and total AMSaerosol could largely be explained by "season of the year" and "position of site". Precedent meta-analyses on aerosol chemical composition did not investigate this relationship or focused on "type of site" (e.g., Hueglin et al., 2005; Zhang et al., 2007). As far as we are aware, the presented approach of explaining relative aerosol compositions is novel. Detailed analyses for other regions of the world will be necessary to validate this finding.

- We found lower overall sulfate loadings (at about $2 \mu \mathrm{g} \mathrm{m}^{-3}$ ) for 2002-2009 than previous studies (Putaud et al., 2004; and Hueglin et al., 2005), which however focused on offline filter measurements. Future AMS studies are necessary to unambiguously attribute this trend to changes in policy ( $\mathrm{SO}_{2}$ emission reductions) rather than different instrumentation (online AMS measurements of submicron non-refractory aerosol vs. offline $\mathrm{PM}_{2.5}$ or $\mathrm{PM}_{10}$ filter analyses).

- It was found that OOA (mostly representing SOA, potentially also including a certain amount of OPOA, i.e. particulate organics that were primarily emitted, evaporated, reacted in the gas-phase and recondensed; Don- ahue et al., 2009) could be separated into a semi-volatile and a low-volatility fraction for all summer campaigns at Swiss Plateau sites (due to the large variability in photochemistry, temperature ranges, and OOA chemical signatures). To get a complete picture, further AMS campaigns should take place, e.g. in Alpine valleys during the summer season.

- Concerning the fact that OOA splits into two fractions for all summer campaigns, we hypothesize that the temperature ranges (on a diurnal level) could drive the successful separation of SV-OOA and LV-OOA. This finding (diurnal temperature variability as the driving agent for the separation of OOA into LV-OOA and SV-OOA by means of FA-AMS) could serve as working hypothesis for future studies.

- The present article evidences the very important impact of wood combustion on ambient OA in Central Europe in a more exhaustive manner than the previous case studies (the importance of wood combustion in residential areas was previously reported for single areas, e.g., by Favez et al., 2009). In addition to providing an estimate of the BBOA impact on NR-PM ${ }_{1}$, we evidence the seasonality and general validity of the strong BBOA impact in the Alpine area. In this study, wood burning OA (BBOA) was identified as a main OA source in Central Europe by means of factor analytical modeling of AMS spectral data (FA-AMS) and this latter approach could be tested for other types of BBOA in other regions of the world, e.g. wild fires in the tropics.

\section{Supplementary material related to this article is available online at: http://www.atmos-chem-phys.net/10/10453/2010/ acp-10-10453-2010-supplement.pdf.}

Acknowledgements. Concerning the field campaigns in Switzerland and in the Rhine Valley we acknowledge funding of the Swiss Federal Office for the Environment (FOEN), Liechtenstein, Land Vorarlberg (Austria), Ostluft, the Cantons Grisons, Valais, St. Gallen, Zurich, and Lucerne, as well as EUCAARI (Jungfraujoch campaign). We thank U. Pöschl and C. Schauer (EC data for $\mathrm{MOHp})$, the MOHp staff $\left(\mathrm{NO}_{\mathrm{x}}\right.$ and $\left.\mathrm{CO}\right)$, as well as the International Foundation High Altitude Research Stations Jungfraujoch and Gornergrat (HFSJG). The Grenoble campaign was part of the FORMES program, funded under the PRIMEQUAL2 grant no. 0001135. Antoinette Boréave is gratefully acknowledged for her help in the field and within data analysis. P. F. DeCarlo is grateful for postdoctoral research support from the US-NSF (IRFP $\sharp 0701013$ ). We further acknowledge funding by Imbalance (http://www.cces.ethz.ch/projects/clench/imbalance). We finally would like to thank Michel Tinguely for designing Fig. 1 and the two anonymous referees for the many constructive comments that greatly improved this paper.

Edited by: T. Koop 


\section{References}

Aceves, M. and Grimalt J. O.: Seasonally dependent size distributions of aliphatic and polycyclic aromatic hydrocarbons in urban aerosols from densely populated areas, Environ. Sci. Technol., 27, 2896-2908, 1993.

Aiken, A. C., DeCarlo, P., Kroll, J. H., Worsnop, D. R., Huffman, J. A., Docherty, K., Ulbrich, I. M., Mohr, C., Kimmel, J. R., Sueper, D., Zhang, Q., Sun, Y. L., Trimborn, A., Northway, M., Ziemann, P. J., Canagaratna, M., Alfarra, M. R., Prévôt, A. S. H., Dommen, J., Duplissy, A., Metzger, A., Baltensperger, U., and Jimenez, J. $\mathrm{L}$.: $\mathrm{O} / \mathrm{C}$ and $\mathrm{OM} / \mathrm{OC}$ ratios of primary, secondary, and ambient organic aerosols with high-resolution time-of-flight aerosol mass spectrometry, Environ. Sci. Technol., 42, 4478-4485, 2008.

Alfarra, M. R.: Insights into Atmospheric Organic Aerosols Using an Aerosol Mass Spectrometer, Ph.D. thesis, University of Manchester Institute of Science and Technology (UMIS), Manchester, 2004.

Alfarra, M. R., Coe, H., Allan, J. D., Bower, K. N., Boudries, H., Canagaratna, M. R., Jimenez, J. L., Jayne, J. T., Garforth, A., Li, S.-M., and Worsnop, D. R.: Characterization of urban and regional organic aerosols in the lower Fraser Valley using two Aerodyne Aerosol Mass Spectrometers, Atmos. Environ., 38, 5745-5758, 2004.

Alfarra, M. R., Prévôt, A. S. H., Szidat, S., Sandradewi, J., Weimer, S., Lanz, V. A., Schreiber, D., Mohr, M., and Baltensperger, U.: Identification of the mass spectral signature of organic aerosols from wood burning emissions, Environ. Sci. Technol., 41, 57705777, 2007.

Allan, J. D., Jimenez, J. L., Williams, P. I., Alfarra, M. R., Bower, K. N., Jayne, J. T., Coe, H., and Worsnop, D. R.: Quantitative sampling using an Aerodyne aerosol mass spectrometer 1. Techniques of data interpretation and error analysis, J. Geophys. Res.-Atmos., 108(D3), 4090, doi:10.1029/2002JD002358, 2003.

Allan, J. D., Delia, A. E., Coe, H., Bower, K. N., Alfarra, M. R., Jimenez, J. L., Middlebrook, A. M., Drewnick, F., Onasch, T. B., Canagaratna, M. R., Jayne, J. T., and Worsnop, D. R.: A generalised method for the extraction of chemically resolved mass spectra from aerodyne aerosol mass spectrometer data, J. Aerosol Sci., 35, 909-922, 2004.

Allan, J. D., Williams, P. I., Morgan, W. T., Martin, C. L., Flynn, M. J., Lee, J., Nemitz, E., Phillips, G. J., Gallagher, M. W., and Coe, H.: Contributions from transport, solid fuel burning and cooking to primary organic aerosols in two UK cities, Atmos. Chem. Phys., 10, 647-668, doi:10.5194/acp-10-647-2010, 2010.

Canagaratna, M. R., Jayne, J. T., Ghertner, D. A., Herndon, S., Shi, Q., Jimenez, J. L., Silva, P. J., Williams, P., Lanni, T., Drewnick, F., Demerjian, K. L., Kolb, C. E., and Worsnop, D. R.: Chase studies of particulate emissions from in-use New York city vehicles, Aerosol Sci. Technol., 38, 555-573, doi:10.1080/02786820490465504, 2004.

Canagaratna, M. R., Jayne, J. T., Jimenez, J. L., Allan, J. D., Alfarra, M. R., Zhang, Q., Onasch, T. B., Drewnick, F., Coe, H., Middlebrook, A., Delia, A., Williams, L. R., Trimborn, A. M., Northway, M. J., DeCarlo, P. F., Kolb, C. E., Davidovits, P., and Worsnop, D. R.: Chemical and microphysical characterization of ambient aerosols with the aerosol mass spectrometer, Mass Spectrom. Rev., 26, 185-222, 2007.

Capes, G., Johnson, B., McFiggans, G., Williams, P. I., Haywood,
J., and Coe, H.: Aging of biomass burning aerosols over West Africa: Aircraft measurements of chemical composition, microphysical properties, and emission ratios, J. Geophys. Res., 113, D00C15, doi:10.1029/2008JD009845, 2008.

Caseiro, A., Bauer, H., Schmidl, C., Pio, C. A., and Puxbaum, H.: Wood burning impact on $\mathrm{PM}_{10}$ in three Austrian regions, Atmos. Environ, 43, 2186-2195, 2009.

Chirico, R., DeCarlo, P. F., Heringa, M. F., Tritscher, T., Richter, R., Prevot, A. S. H., Dommen, J., Weingartner, E., Wehrle, G., Gysel, M., Laborde, M., and Baltensperger, U.: Impact of aftertreatment devices on primary emissions and secondary organic aerosol formation potential from in-use diesel vehicles: results from smog chamber experiments, Atmos. Chem. Phys. Discuss., 10, 16055-16109, doi:10.5194/acpd-10-16055-2010, 2010.

Colbeck, I.: Physical and chemical properties of aerosols, Blackie Academic and Professional, London, Weinheim, New York, Tokyo, Melbourne, Madras, 1998.

Cottrell, L. D., Griffin, R. J., Jimenez, J. L., Zhang, Q., Ulbrich, I. M., Ziemba, L. D., Beckman, P. J., Sive, B. C., and Talbot, R. W.: Submicron particles at Thompson Farm during ICARTT measured using aerosol mass spectrometry, J. Geophys. Res., 113, D08212, doi:10.1029/2007JD009192, 2008.

Cozic, J., Verheggen, B., Weingartner, E., Crosier, J., Bower, K. N., Flynn, M., Coe, H., Henning, S., Steinbacher, M., Henne, S., Collaud Coen, M., Petzold, A., and Baltensperger, U.: Chemical composition of free tropospheric aerosol for $\mathrm{PM}_{1}$ and coarse mode at the high alpine site Jungfraujoch, Atmos. Chem. Phys., 8, 407-423, doi:10.5194/acp-8-407-2008, 2008.

Crosier, J., Allan, J. D., Coe, H., Bower, K. N., Formenti, P., and Williams, P. I.: Chemical composition of summertime aerosol in the Po Valley (Italy), Northern Adriatic and Black Sea, Q. J. Roy. Meteor. Soc., 133, 61-75, doi:10.1002/qj.88, 2007.

DeCarlo, P. F., Kimmel, J. R., Trimborn, A., Northway, M. J., Jayne, J. T., Aiken, A. C., Gonin, M., Fuhrer, K., Horvath, T., Docherty, K. S., Worsnop, D. R., and Jimenez, J. L.: Field-deployable, high-resolution, time-of-flight aerosol mass spectrometer, Anal. Chem., 78, 8281-8289, 2006.

DeCarlo, P. F., Dunlea, E. J., Kimmel, J. R., Aiken, A. C., Sueper, D., Crounse, J., Wennberg, P. O., Emmons, L., Shinozuka, Y., Clarke, A., Zhou, J., Tomlinson, J., Collins, D. R., Knapp, D., Weinheimer, A. J., Montzka, D. D., Campos, T., and Jimenez, J. L.: Fast airborne aerosol size and chemistry measurements above Mexico City and Central Mexico during the MILAGRO campaign, Atmos. Chem. Phys., 8, 4027-4048, doi:10.5194/acp8-4027-2008, 2008.

DeCarlo, P. F., Ulbrich, I. M., Crounse, J., de Foy, B., Dunlea, E. J., Aiken, A. C., Knapp, D., Weinheimer, A. J., Campos, T., Wennberg, P. O., and Jimenez, J. L.: Investigation of the sources and processing of organic aerosol over the Central Mexican Plateau from aircraft measurements during MILAGRO, Atmos. Chem. Phys., 10, 5257-5280, doi:10.5194/acp-10-52572010, 2010.

Docherty, K. S., Stone, E. A., Ulbrich, I. M., DeCarlo, P. F., Snyder, D. C., Schauer, J. J., Peltier, R. E., Weber, R. J., Murphy, S. M., Seinfeld, J. H., Eatough, D. J., and Jimenez, J. L.: Apportionment of primary and secondary organic aerosols in Southern California during the 2005 Study of Organic Aerosols in Riverside (SOAR), Environ. Sci. Technol., 42, 7655-7662, 2008.

Donahue, N. M., Robinson, A. L., and Pandis, S. N.: Atmospheric 
organic particulate matter: From smoke to secondary organic aerosol, Atmos. Environ., 43, 94-106, 2009.

Drewnick, F., Schwab, J. J., Jayne, J. T., Canagaratna, M., Worsnop, D. R., and Demerjian, K. L.: Measurement of ambient aerosol composition during the PMTACS-NY 2001 using an aerosol mass spectrometer. Part II: chemically speciated mass distributions, Aerosol Sci. Technol., 38, 92-103, 2004.

Drewnick, F., Hings, S. S., DeCarlo, P. F., Jayne, J. T., Gonin, M., Fuhrer, K., Weimer, S., Jimenez, J. L., Demerjian, K. L., Borrmann, S., Worsnop, D. R.: A new Time-of-Flight Aerosol Mass Spectrometer (ToF-AMS)-Instrument description and first field deployment, Aerosol Sci. Technol., 39, 637-658, 2005.

Drewnick, F., Hings, S. S., Alfarra, M. R., Prevot, A. S. H., and Borrmann, S.: Aerosol quantification with the Aerodyne Aerosol Mass Spectrometer: detection limits and ionizer background effects, Atmos. Meas. Tech., 2, 33-46, doi:10.5194/amt-2-332009, 2009.

Dzepina, K., Arey, J., Marr, L. C., Worsnop, D. R., Salcedo, D., Zhang, Q., Onasch, T. B., Molina, L. T., Molina, M. J. and Jimenez, J. L.: Detection of particle-phase polycyclic aromatic hydrocarbons in Mexico city using an aerosol mass spectrometer, Int. J. Mass Spec., 263, 152-170, 2007.

Favez, O., Cachier, H., Sciare, J., Sarda-Eséve, R., and Martinon, L.: Evidence for a significant contribution of wood burning aerosols to PM2.5 during the winter season in Paris, France, Atmos. Environ., 43, 3640-3644, 2009.

Favez, O., El Haddad, I., Piot, C., Boréave, A., Abidi, E., Marchand, N., Jaffrezo, J.-L., Besombes, J.-L., Personnaz, M.-B., Sciare, J., Wortham, H., George, C., and D'Anna, B.: Inter-comparison of source apportionment models for the estimation of wood burning aerosols during wintertime in an Alpine city (Grenoble, France), Atmos. Chem. Phys., 10, 5295-5314, doi:10.5194/acp-10-52952010, 2010.

Forster, P., Ramaswamy, V., Artaxo, P., Berntsen, T., Betts, R., Fahey, D. W., Haywood, J., Lean, J., Lowe, D. C., Myhre, G., Nganga, J., Prinn, R., Raga, G., Schulz, M., and Van Dorland, R.: Changes in Atmospheric Constituents and in Radiative Forcing, in: Climate Change 2007: The Physical Science Basis. Contribution of Working Group I to the Fourth Assessment Report of the Intergovernmental Panel on Climate Change, edited by: Solomon, S., Qin, D., Manning, M., Chen, Z., Marquis, M., Averyt, K. B., Tignor, M., and Miller, H. L., Cambridge University Press, Cambridge, United Kingdom and New York, NY, USA, 2007.

Glasius, M., Ketzel, M., Wahlin, P., Jensen, B., Monster, J., Berkowicz, R., and Palmgren, F.: Impact of wood combustion on particle levels in a residential area in Denmark, Atmos. Environ., 40, 7115-7124, 2006.

Grieshop, A. P., Logue, J. M., Donahue, N. M., and Robinson, A. L.: Laboratory investigation of photochemical oxidation of organic aerosol from wood fires 1: measurement and simulation of organic aerosol evolution, Atmos. Chem. Phys., 9, 1263-1277, doi:10.5194/acp-9-1263-2009, 2009.

HBEFA: Handbuch fr Emissionsfaktoren des Strassenverkehrs (handbook of emission factors for road traffic), Umweltbundesamt Berlin, Bundesamt füur Umwelt, Wald und Landschaft Bern, Infras AG, Bern (published on CD-ROM, also available at: www.hbefa.net), 2004

Hedberg, E. and Johansson, C.: Is levoglucosan a suitable quantita- tive tracer for wood burning? Comparison with receptor modeling on trace elements in Lycksele, Sweden, J. Air Waste Manage. Assoc., 56, 1669-1678, 2006.

Henning, S., Weingartner, E., Schwikowski, M., Gaggeler, H. W., Gehrig, R., Hinz, K. P., Trimborn, A., Spengler, B., and Baltensperger, U.: Seasonal variation of water-soluble ions of the aerosol at the high-alpine site Jungfraujoch (3580 m asl), J. Geophys. Res.-Atmos., 108(D1), 4030, doi:10.1029/2002JD002439, 2003.

Herndon, S.C., Onasch, T. B., Wood, E. C., Kroll, J. H., Canagaratna, M. R., Jayne, J. T., Zavala, M. A., Knighton, W. B., Mazzoleni, C., Dubey, M. K., Ulbrich, I. M., Jimenez, J. L., Seila, R., de Gouw, J. A., de Foy, B., J. Fast, J., Molina, L. T., Kolb, C. E., and Worsnop, D. R.: Correlation of secondary organic aerosol with odd oxygen in Mexico City, Geophys. Res. Lett., 35, L15804, doi:10.1029/2008GL034058, 2008.

Hitzenberger, R., Petzold, A., Bauer, H., Ctyroky, P., Pouresmaeil, P., Laskus, L., and Puxbaum, H.: Intercomparison of thermal and optical measurement methods for elemental carbon and black carbon at an urban location, Environ. Sci. Technol., 40, 63776383, 2006.

Hock, N., Schneider, J., Borrmann, S., Römpp, A., Moortgat, G., Franze, T., Schauer, C., Pöschl, U., Plass-Dülmer, C., and Berresheim, H.: Rural continental aerosol properties and processes observed during the Hohenpeissenberg Aerosol Characterization Experiment (HAZE2002), Atmos. Chem. Phys., 8, 603-623, doi:10.5194/acp-8-603-2008, 2008.

Hueglin, C., Gehrig, R., Baltensperger, U., Gysel, M., Monn, C., and Vonmont, H.: Chemical characterisation of PM2.5, PM10 and coarse particles at urban, near-city and rural sites in Switzerland, Atmos. Environ., 39, 637-651, 2005.

Huffman, J. A., Docherty, K. S., Aiken, A. C., Cubison, M. J., Ulbrich, I. M., DeCarlo, P. F., Sueper, D., Jayne, J. T., Worsnop, D. R., Ziemann, P. J., and Jimenez, J. L.: Chemically-resolved aerosol volatility measurements from two megacity field studies, Atmos. Chem. Phys., 9, 7161-7182, doi:10.5194/acp-9-71612009, 2009.

IPCC Fourth Assessment Report: The Physical Science Basis, Working Group I, Final Report, Geneva, Switzerland, available from: http://www.ipcc.ch/ipccreports/ar4-wg1.htm, 2007.

IEA (International Energy Agency): Energy efficiency indicators for public electricity production from fossil fuels, OECD/IEA, Paris, available at: http://www.iea.org/ Papers/2008/cd_energy_efficiency_policy/7-Energy\%20utilities/ 7-En_Efficiency_Indicators.pdf, 2008.

Jayne, J. T., Leard, D. C., Zhang, X. F., Davidovits, P., Smith, K. A., Kolb, C. E., and Worsnop, D. R.: Development of an aerosol mass spectrometer for size and composition analysis of submicron particles, Aerosol Sci. Tech., 33, 49-70, 2000.

Jimenez, J. L., Jayne, J. T., Shi, Q., Kolb, C. E., Worsnop, D. R., Yourshaw, I., Seinfeld, J. H., Flagan, R. C., Zhang, X. F., Smith, K. A., Morris, J. W., and Davidovits, P.: Ambient aerosol sampling using the Aerodyne aerosol mass spectrometer, J. Geophys. Res.-Atmos., 108(D7), 8425, doi:8410.1029/2001JD001213, 2003.

Jimenez, J. L., Canagaratna, M. R., Donahue, N. M., et al.: Evolution of organic aerosols in the atmosphere, Science, 326, 15251529, 2009.

Kleinman, L. I., Daum, P. H., Lee, Y.-N., et al.: Aircraft observa- 
tions of aerosol composition in New England and mid-Atlantic states during the summer 2002 NEAQS field campaign, J. Geophys. Res., 112, D09310, doi:10.1029/2006JD007786, 2007.

Lanz, V. A., Alfarra, M. R., Baltensperger, U., Buchmann, B., Hueglin, C., and Prévôt, A. S. H.: Source apportionment of submicron organic aerosols at an urban site by factor analytical modelling of aerosol mass spectra, Atmos. Chem. Phys., 7, 1503-1522, doi:10.5194/acp-7-1503-2007, 2007.

Lanz, V. A., Alfarra, M. R., Baltensperger, U., Buchmann, B., Hueglin, C., Szidat, S., Wehrli, M. N., Wacker, L., Weimer, S., Caseiro, A., Puxbaum, H., and Prévôt, A. S. H.: Source attribution of submicron organic aerosols during wintertime inversions by advanced factor analysis of aerosol mass spectra, Environ. Sci. Technol., 42, 214-220, 2008.

Leu, M.-T., Timonen, R. S., and Keyser, L. F.: Heterogeneous reactions of $\mathrm{HNO} 3(\mathrm{~g})+\mathrm{NaCl}(\mathrm{s}) \longrightarrow \mathrm{HCl}(\mathrm{g})+\mathrm{NaNO} 3(\mathrm{~g})$ and $\mathrm{N} 2 \mathrm{O} 5(\mathrm{~g})+\mathrm{NaCl}(\mathrm{s}) \longrightarrow \mathrm{ClNO} 2(\mathrm{~g})+\mathrm{NaNO} 3(\mathrm{~s})$, J. Phys. Chem., 1995, 13203-13212, 1995.

Lipsky, E. M. and Robinson, A. L.: Effects of dilution on fine particle mass and partitioning of semivolatile organics in diesel exhaust and wood smoke, Environ. Sci. Technol., 40, 155-162, 2006.

Liu, P. S. K., Deng, R., Smith, K. A., Williams, L. R., Jayne, J. T., Canagaratna, M. R., Moore, K., Onasch, T. B., Worsnop, D. R., and Deshler, T.: Transmission efficiency of an aerodynamic focusing lens system: comparison of model calculations and laboratory measurements for the Aerodyne aerosol mass spectrometer, Aerosol Sci. Technol., 41, 721-733, 2007.

Lövblad, G., Tarrason, L., and Tørseth, K.: EMEP Assessment Part I - European Perspective, Chapter 2: Sulphur, available at: http://www.emep.int/assessment/Part1/025-056_ 02-Sulphur-Part1.pdf, 2004.

Lugauer, M. Baltensperger, U., Furger, M., Gaeggeler, H. W., Jost, D. T., Nyeki, S., and Schwikowski, M.: Influences of vertical transport and scavenging on aerosol particle surface area and Radon decay product concentrations at the Jungfraujoch (3454 m a.s.1.), J. Geophys. Res., 105, 19869-19879, 2000.

Matson, P., Lohse, K. A., and Hall, S. J.: The globalization of nitrogen deposition: Consequences for terrestrial ecosystems, Ambio, 31, 113-119, 2002.

Matthew, B. M., Middlebrook, A. M., and Onasch, T. B.: Collection efficiencies in an aerodyne aerosol mass spectrometer as a function of particle phase for laboratory generated aerosols, Aerosol Sci. Technol., 42, 884-898, 2008.

Mohr, C., Weimer, S., Lanz, V. A., et al.: Organic aerosol source apportionment using mass spectra from mobile measurements in the Rhine Valley, in preparation, 2010.

Nemitz, E., Jimenez, J. L., Huffman, J. A., Ulbrich, I. M., Canagaratna, M. R., Worsnop, D. R., and Guenther, A. B.: An eddycovariance system for the measurement of surface/atmosphere exchange fluxes of submicron aerosol chemical species - First application above an urban area, Aerosol Sci. Tech., 42, 636657, doi:10.1080/02786820802227352, 2008.

Ng, N. L., Canagaratna, M. R., Zhang, Q., Jimenez, J. L., Tian, J., Ulbrich, I. M., Kroll, J. H., Docherty, K. S., Chhabra, P. S., Bahreini, R., Murphy, S. M., Seinfeld, J. H., Hildebrandt, L., Donahue, N. M., DeCarlo, P. F., Lanz, V. A., Prévôt, A. S. H., Dinar, E., Rudich, Y., and Worsnop, D. R.: Organic aerosol components observed in Northern Hemispheric datasets from
Aerosol Mass Spectrometry, Atmos. Chem. Phys., 10, 46254641, doi:10.5194/acp-10-4625-2010, 2010.

Paatero, P. and Tapper, U.: Analysis of different modes of factoranalysis as least-squares fit problems, Chemometrics Intell. Lab. Syst., 8, 183-194, 1993.

Paatero, P. and Tapper, U.: Positive matrix factorization: a nonnegative factor model with optimal utilization of error estimates of data values, Environmetrics, 5, 111-126, 1994.

Paatero, P.: The multilinear engine - A table-driven, least squares program for solving multilinear problems, including the n-way parallel factor analysis model, J. Comp. Graph. Stat., 8, 854-888, 1999.

Peng, R. D., Dominici, F., Pastor-Barriuso, R., Zeger, S. L., and Samet, J. M.: Seasonal analyses of air pollution and mortality in 100 US cities, Am. J. Epidem., 161, 585-594, 2005.

Perraudin, E., Budzinski, H., and Villenave, E.: Kinetic study of the reactions of ozone with polycyclic aromatic hydrocarbons adsorbed on atmospheric model particles, J. Atmos. Chem., 56, 57-82, 2007.

Perron, N., Sandradewi, J., Alfarra, M. R., Lienemann, P., Gehrig, R., Kasper-Giebl, A., Lanz, V. A., Szidat, S., Ruff, M., Fahrni, S., Wacker, L., Baltensperger, U., and Prévôt, A. S. H.: Composition and sources of particulate matter in an industrialised Alpine valley, Atmos. Chem. Phys. Discuss., 10, 9391-9430, doi:10.5194/acpd-10-9391-2010, 2010.

Putaud, J.-P., Raes, F., Van Dingenen, R., et al.: A European aerosol phenomenology - 2: chemical characteristics of particulate matter at kerbside, urban, rural and background sites in Europe, Atmos. Environ., 38, 2579-2595, 2004.

Ramgolam, K., Favez, O., Cachier, H., Gaudichet, A., Marano, F., Martinon, L., and Baeza-Squiban, A.: Size-partitioning of an urban aerosol to identify particle determinants involved in the proinflammatory response induced in airway epithelial cells, Part. Fibre Toxicol., 6(10), doi:10.1186/1743-8977-6-10, 2009.

Sandradewi, J., Prévôt, A. S. H., Szidat, S., Perron, N., Alfarra, M. R., Lanz, V. A., Weingartner, E., and Baltensperger, U.: Using aerosol light absorption measurements for the quantitative determination of wood burning and traffic emission contributions to particulate matter, Environ. Sci. Technol., 42, 3316-3323, doi:10.1021/es702253m, 2008a.

Sandradewi, J., Prévôt, A. S. H., Weingartner, E., Schmidhauser, R., Gysel, M., and Baltensperger, U.: A study of wood burning and traffic aerosols in an Alpine valley using a multi-wavelength Aethalometer, Atmos. Environ., 42, 101-112, 2008 b.

Schneider, J., Weimer, S., Drewnick, F., Borrmann, S., Helas, G., Gwaze, P., Schmid, O., Andreae, M. O., and Kirchner, U.: Mass spectrometric analysis and aerodynamic properties of various types of combustion-related aerosol particles, Int. J. Mass. Spec., 258, 37-49, 2006.

Slowik, J. G., Vlasenko, A., McGuire, M., Evans, G. J., and Abbatt, J. P. D.: Simultaneous factor analysis of organic particle and gas mass spectra: AMS and PTR-MS measurements at an urban site, Atmos. Chem. Phys., 10, 1969-1988, doi:10.5194/acp-10-19692010, 2010.

Sun, J. Y., Zhang, Q., Canagaratna, M. R., Zhang, Y. M., Ng, N. L., Sun, Y. L., Jayne, J. T., Zhang, X. C., Zhang, X. Y., and Worsnop, D. R.: Highly time- and size-resolved characterization of submicron aerosol particles in Beijing using an Aerodyne aerosol mass spectrometer, Atmos. Environ., 44, 131-140, 
110.1016/j.atmosenv.2009.1003.1020, 2010.

Szidat, S., Prévôt, A. S. H., Sandradewi, J., Alfarra, M. R., Synal, H.-A., Wacker, L., and Baltensperger, U.: Dominant impact of residential wood burning on particulate matter in Alpine valleys during winter, Geophys. Res. Lett., 34, L05820, doi:10.1029/2006GL028325, 2007.

Takegawa, N., Miyakawa, T., Kondo, Y., Jimenez, J. L., Zhang, Q., Worsnop, D. R., and Fukuda, M.: Seasonal and diurnal variations of submicron organic aerosol in Tokyo observed using the Aerodyne aerosol mass spectrometer, J. Geophys. Res., 111, D11206, doi:10.1029/2005JD006515, 2006.

Takegawa, N., Miyakawa, T., Watanabe, M., Kondo, Y., Miyazaki, Y., Han, S., Zhao, Y., van Pinxteren, D., Bruggemann, E., Gnauk, T., Herrmann, H., Xiao, R., Deng, Z., Hu, M., Zhu, T., and Zhang, Y.: Performance of an Aerodyne aerosol mass spectrometer (AMS) during intensive campaigns in China in the summer of 2006, Aerosol Sci. Technol., 43, 189-204, 2009.

Ulbrich, I. M., Canagaratna, M. R., Zhang, Q., Worsnop, D. R., and Jimenez, J. L.: Interpretation of organic components from Positive Matrix Factorization of aerosol mass spectrometric data, Atmos. Chem. Phys., 9, 2891-2918, doi:10.5194/acp-9-2891-2009, 2009.

Umweltbundesamt: http://www.umweltbundesamt.at/ umweltschutz/verkehr/kraftstoffe/(last access: November 2010), 2007.

Watson, J. G.: Visibility: science and regulation, J. Waste Air Manage., 52, 628-713, 2002.

Weimer, S., Drewnick, F., Hogrefe, O., Schwab, J. J., Rhoads, K., Orsini, D., Canagaratna, M., Worsnop, D. R., and Demerjian, K. L.: Size-selective nonrefractory ambient aerosol measurements during the Particulate Matter Technology Assessment and Characterization Study-New York 2004 Winter Intensive in New York City, J. Geophys. Res., 111, D18305, doi:10.1029/2006JD007215, 2006.

Weimer, S., Alfarra, M. R., Schreiber, D., Mohr, M., Prévôt, A. S. H., and Baltensperger, U.: Organic aerosol mass spectral signatures from wood-burning emissions: influence of burning conditions and wood type, J. Geophys. Res., 113, D10304, doi:10.1029/2007JD009309, 2008.
Wexler, A. S. and Seinfeld, J. H.: The distribution of ammonium salts among a size and compositional dispersed aerosol, Atmos. Environ., 24A, 1231-1246, 1990.

Yttri, K. E., Dye, C., Braathen, O.-A., Simpson, D., and Steinnes, E.: Carbonaceous aerosols in Norwegian urban areas, Atmos. Chem. Phys., 9, 2007-2020, doi:10.5194/acp-9-2007-2009, 2009.

Zdráhal, Z., Oliveira, J., Vermeylen, R., Claeys, M., and Maenhaut, W.: Improved method for quantifying levoglucosan and related monosaccharide anhydrides in atmospheric aerosols and application to samples from urban and tropical locations, Environ. Sci. Technol., 36, 747-753, 2002.

Zhang, Q., Alfarra, M. R., Worsnop, D. R., Allan, J. D., Coe, H., Canagaratna, M. R., and Jimenez, J. L.: Deconvolution and quantification of hydrocarbon-like and oxygenated organic aerosols based on aerosol mass spectrometry, Environ. Sci. Technol., 39, 4938-4952, 2005a.

Zhang, Q., Canagaratna, M. R., Jayne, J. T., Worsnop, D. R., and Jimenez, J. L.: Time and size-resolved chemical composition of submicron particles in Pittsburgh - Implications for aerosol sources and processes, J. Geophys. Res., 110, D07S09, doi:10.1029/2004JD004649, 2005b.

Zhang, Q., Jimenez, J. L., Canagaratna, M. R., Allan, J. D., Coe, H., Ulbrich, I. M., Alfarra, M. R., Takami, A., Middlebrook, A M., Sun, Y. L., Dzepina, K., Dunlea, E. A., Docherty, K. S., DeCarlo, P. F., Salcedo, D., Onasch, T., Jayne, J. T., Miyoshi, T., Shimono, A., Hatakeyama, S., Takegawa, N., Kondo, Y., Schneider, J., Drewnick, F., Borrmann, S., Weimer, S., Demerjian, K., Williams, P., Bower, K., Bahreini, R., Cottrell, L., Griffin, R. J., Rautiainen, J., Sun, J. Y., Zhang, Y. M., and Worsnop, D. R.: Ubiquity and dominance of oxygenated species in organic aerosols in anthropogenically-influenced Northern Hemisphere midlatitudes, Geophys. Res. Lett., 34, L13801, doi:13810.11029/12007GL029979, 2007a.

Zhang, Q., Jimenez, J. L., Worsnop, D. R., and Canagaratna, M. R.: A case study of urban particle acidity and its influence on secondary organic aerosol, Environ. Sci. Technol., 41, 3213-3219, $2007 b$. 